University of Louisville

ThinkIR: The University of Louisville's Institutional Repository

Electronic Theses and Dissertations

8-2015

\title{
"What role we, as Negro youth of America, could play" : a new history of the Louisville NAACP youth, 1937-1955.
}

Alexis Monique Johnson

University of Louisville

Follow this and additional works at: https://ir.library.louisville.edu/etd

Part of the Race, Ethnicity and Post-Colonial Studies Commons

\section{Recommended Citation}

Johnson, Alexis Monique, "'What role we, as Negro youth of America, could play" : a new history of the Louisville NAACP youth, 1937-1955." (2015). Electronic Theses and Dissertations. Paper 2206.

https://doi.org/10.18297/etd/2206

This Master's Thesis is brought to you for free and open access by ThinkIR: The University of Louisville's Institutional Repository. It has been accepted for inclusion in Electronic Theses and Dissertations by an authorized administrator of ThinkIR: The University of Louisville's Institutional Repository. This title appears here courtesy of the author, who has retained all other copyrights. For more information, please contact thinkir@louisville.edu. 
"WHAT ROLE WE, AS NEGRO YOUTH OF AMERICA, COULD PLAY":

A NEW HISTORY OF THE LOUISVILLE NAACP YOUTH, 1937-1955

\title{
By
}

Alexis Monique Johnson

B.A., Francis Marion University, 2013

\begin{abstract}
A Thesis
Submitted to the Faculty of the College of Arts and Sciences of the University of Louisville

In Partial Fulfillment of the Requirements for the Degree of
\end{abstract}

Master of Arts in Pan-African Studies

Department of Pan-African Studies

University of Louisville Louisville, KY

August 2015 
Copyright 2015 by Alexis M. Johnson

All rights reserved 

"WHAT ROLE WE, AS NEGRO YOUTH OF AMERICA COULD PLAY":

A NEW HISTORY OF THE LOUISVILLE NAACP YOUTH COUNCIL, 1937-1955

By

Alexis Monique Johnson

B.A., Francis Marion University, 2013

A Thesis Approved on

May 28, 2015

By the following Thesis Committee:

Dr. Theresa Rajack-Talley

Dr. Shirletta Kinchen

Dr. Cate Fosl 


\section{DEDICATION}

This thesis is dedicated to the life and memory of LuAnne Patterson and Ophelia Ellerbe. 


\section{ACKNOWLEDGEMENTS}

First, I would like to thank Jesus Christ, for without whom, nothing, especially the writing of this thesis, is possible. Next, I would like to thank my committee. I could not have asked for a better one. To my thesis chair, Dr. Rajack-Talley, thank you for your for unwavering support, for pushing me to become a better writer, and for believing in me when I didn't believe in myself. To my other committee members, Dr. Kinchen and Dr. Fosl, thank you for your wonderful mentorship. Both of you have shaped my development as a young scholar in ways you'll never know. This thesis is both a culmination and reflection of all that I have learned as a student in the Department of Pan-African Studies and as a graduate assistant in the Anne Braden Institute. Thank you to the faculty, staff, and my wonderful colleagues — now lifelong friends — of the Department and the Institute- I love you all. Lastly, thank you to my family for your love, support, and encouragement. Words cannot express my gratitude. 


\begin{abstract}
"WHAT ROLE WE, AS NEGRO YOUTH OF AMERICA, COULD PLAY":

A NEW HISTORY OF THE LOUISVILLE NAACP YOUTH COUNCIL, 1937—1955
\end{abstract}

Alexis Monique Johnson

May 28, 2015

Utilizing the archival Papers of the NAACP, The Louisville Leader, and The Crisis, this thesis narrates the history of the youth arm of the NAACP in Louisville, Kentucky, from 1937 until 1955, previously undocumented in the written record. First organized in September 1937, the Louisville NAACP Youth Council, alongside the college chapter at Louisville Municipal College, sponsored an anti-lynching campaign in 1938. The Youth Council also attended the $29^{\text {th }}$ annual NAACP conference in 1938 , and sent a delegate to the National Anti-War Youth Congress in 1939. These activities were situated in a historical moment that saw the proliferation of interracial coalitions, and were reflective of a youth activist trend in the 1930s that centered on protesting racism at home and fascism abroad.

During the first half of the 1940s, war and migration influenced the Louisville NAACP youth arm's political activity. Divided into a West End Youth Council and an East End Youth Council, the groups centered their work on protesting educational inequities and agitating for increased political rights for African Americans. In the postwar period, with the emergence of an interracial college chapter, the youth continued to campaign for racial equality, but their activities would curtail, and ultimately end, by 
the Red Scare that swept the country from the late 1940s to the early 1950s.

One of the first studies of a local NAACP youth group, this thesis offers a contribution to the literature on black youth activism during the early period of the Civil Rights Movement and the role of the NAACP in the black freedom struggle. The findings highlight the significance of social location in research on social movements. 
TABLE OF CONTENTS

PAGE

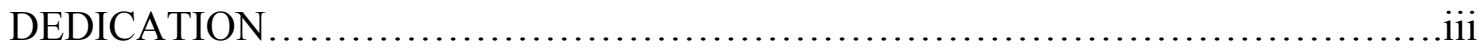

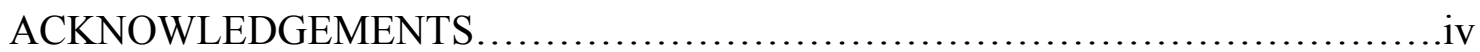

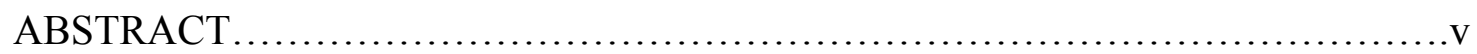

LIST OF TABLES ............................................................

CHAPTER I: INTRODUCTION—“OUR TIME IS NOW”

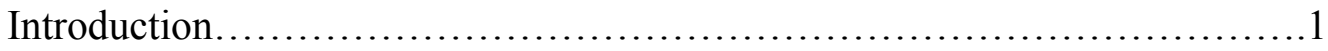

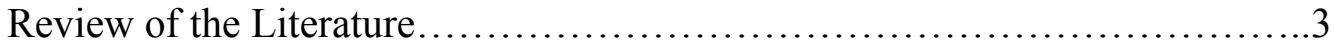

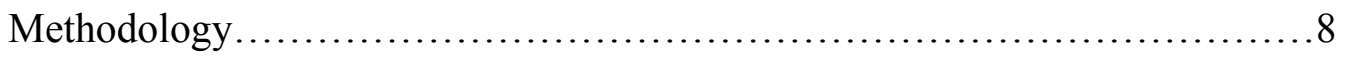

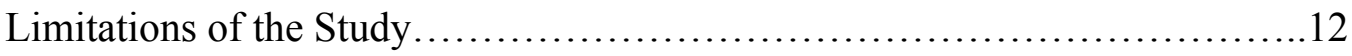

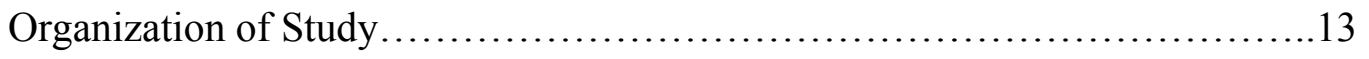

CHAPTER II: "WE MUST ACT—AND ACT NOW": LOUISVILLE NAACP YOUTH:

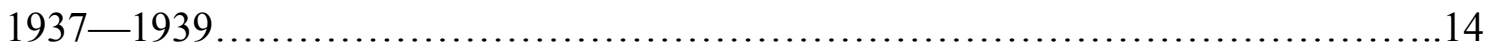

CHAPTER III: “THE TRUE ASPECT OF A MOVEMENT”: LOUISVILLE NAACP

YOUTH IN THE INTERWAR YEARS, 1940-1944_..............................34

CHAPTER IV: "RED SCARED”: LOUISVILLE NAACP YOUTH, 1945-1955_......53

CHAPTER V: CONCLUSION

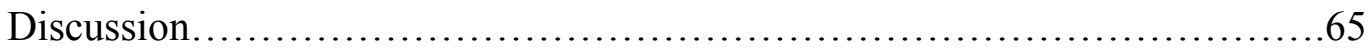

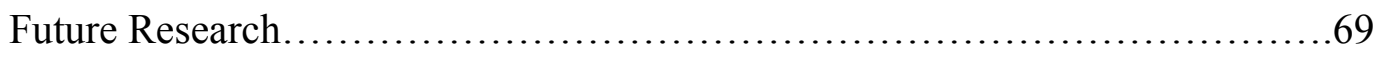

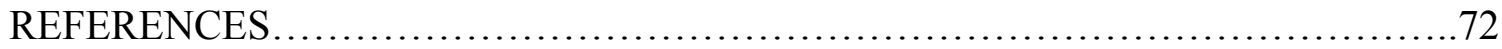

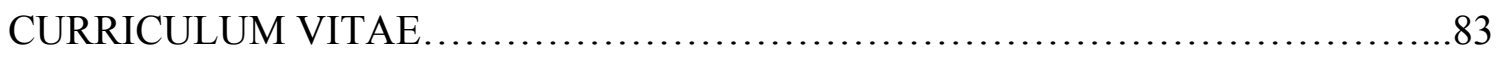




\section{LIST OF TABLES}

TABLE PAGE

1. Data Collection................................................................... 


\section{CHAPTER I: INTRODUCTION}

“OUR TIME IS NOW”

"You're at the forefront of this movement, and as young people, our time is now." Marilyn Mosby, State's Attorney for Baltimore, Maryland ${ }^{1}$

Slain by police officer Darren Wilson on August 9, 2014, 18-year-old Michael Brown lay in the streets for 4.5 hours in Ferguson, Missouri, a black suburb of St. Louis. Freddie Gray, a 25-year-old native of Baltimore, Maryland, suffered a severed spinal cord while in police custody on April 12, 2015. One week later, Gray succumbed to injuries. Both young African American men, Brown and Gray are but two of the casualties amongst countless other black men, women, and transgender individuals who have fallen victim to state-sanctioned violence.

In response to the rampant police brutality that has terrorized African American communities, social movements have erupted in Ferguson and Baltimore. In these border cities, black youth are leading marches, sit-ins, and protests evocative of the Civil Rights Movement. Speaking to activism in the digital age, "Hands Up Don't Shoot" and "Black Lives Matter" both social media campaigns in their embryonic stages, have grown to social movements on the ground, with a local, national, and international reach.

Nearly 80 years ago in Louisville, Kentucky, members of the youth arm of the National Association for the Advancement of Colored People (NAACP) also launched a

\footnotetext{
${ }^{1}$ Mosby in a press conference held on May 1, 2015, recounting the illegal detainment and ultimate death of Freddie Gray, and the charges brought against the six police officers involved.
} 
massive campaign against racialized violence, and then embarked upon over a decade of activism in which they united to seek redress for other manifestations of white supremacy. Organized in 1937, the Louisville NAACP Youth Council campaigned against lynching and militarism for the duration of the 1930s. During the interwar years (1940 - 1944), the Louisville youth fought for educational equality and for increased political rights for African Americans. By 1945, though still active, the Louisville NAACP's youth arm entered into a period of decline, and then underwent a roughly fiveyear period (1950 - 1955), due in large part to the Red Scare, for which their actions are unaccounted.

In 1955, Louisville's NAACP youth re-emerged with Muriel Gregg at the helm, and they pursued the victories for which they are remembered today, specifically the Nothing New for Easter Demonstrations of 1961, which served as a catalyst in Louisville becoming the first city in the South to pass an ordinance banning discrimination in public accommodations. The written record contends that Muriel Gregg organized the youth arm of the Louisville NAACP in 1955, omitting their formative years of activism. The purpose of this thesis, therefore, is to tell the forgotten story of the Louisville NAACP youth, from their founding in 1937 until the point of their major reorganization in 1955. In the sections that follow, I review the literature which aids in underwriting the significance of the study, and I also provide an overview of the methodology utilized to construct this narrative. ${ }^{2}$

\footnotetext{
${ }^{2}$ Patrick S. McElhone's thesis on the Louisville NAACP adult branch provides one mention of the activities of the Louisville Youth Council in 1940. Patrick S. McElhone, "The Civil Rights Activities of the Louisville Branch of the National Association for the Advancement of Colored People: 1914-1960" (Thesis, University of Louisville, 1976), 61. The following sources acknowledge the Louisville NAACP Youth Council's work during the Civil Rights Movement's modern period, but do not discuss their work prior to 1955. Catherine Fosl and Tracey E. K'Meyer, Freedom on the Border: An Oral History of the Civil Rights Movement in Kentucky (Lexington: The University Press of Kentucky, 2009), xiii, 73; Joshua D. Farrington, "Even I Voted Republican”: African American Voters and Public
} 


\title{
REVIEW OF THE LITERATURE
}

\author{
As one of the "world's most complicated indictments,"3 the Civil Rights
}

Movement and its legacies has captured the memory of the public and many scholars of

American history who specialize in the Civil Rights Movement. During the Movement,

African Americans fought equally for economic, political, social, and civil rights. While

these rights were interrelated and overlapped, the extent to which rights assumed the most

prevalence and how these rights were secured was subject to time period, location, the

political ideology of movement leadership, the existence of cross-racial alliances, and the

social, political, and economic state of the country at the given time. ${ }^{4}$

In more recent studies, scholars have shifted their focus on decentering the

Movement and placing emphasis on the "micro rather than a macro level." By

concentrating on local, regional, and less chronicled aspects of the Movement, scholars

\footnotetext{
Accommodations in Louisville, Kentucky, 1960-1961," Register of the Kentucky Historical Society 109, 3 \& 4 (2011); Sarah Garland, Divided We Fail: The Story of an African American Community That Ended the Era of School Desegregation (Boston: Beacon Press, 2013); John E. Kleber, ed., "Civil Rights" in The Encyclopedia of Louisville (Lexington: The University Press of Kentucky, 2001), 191; Tracey E. K'Meyer, Civil Rights in the Gateway to the South: Louisville, Kentucky, 1945-1980 (Lexington: The University of Kentucky Press, 2009), 81-89; August Meier and Elliot Rudwick, Along the Color Line: Explorations in the Black Experience (Champaign: The University of Illinois Press, 1976), 374; August Meier, "Negro Protest Movements and Organizations," The Journal of Negro Education 32, no. 4 (1963); Aldon Morris, "Black Southern Sit-In Movement: An Analysis of Internal Organization," American Sociological Review 46, no. 6 (1981), 748; Mark Newman, The Civil Rights Movement (Westport: Praeger Publishers, 2004), 64. Merill Proudfoot, Diary of a Sit-In (Chapel Hill: The University of North Carolina Press, 1962), xi; Lee Sartain, Borders of Equality: The NAACP and the Civil Rights Struggle, 1914-1970 (Jackson: University Press of Mississippi, 2013), 125; Gerald L. Smith, "Direct Action Protests in the Upper South: Kentucky Chapters of the Congress of Racial Equality," Register of the Kentucky Historical Society 109, 3 \& 4 (2011); Stephan Thernstrom and Abigail Thernstrom, America in Black And White: One Nation Indivisible (New York: Touchstone, 1997), 120; Victoria W. Wolcott, Race, Riots, and Roller Coasters: The Struggle Over Segregated Recreation in America (Philadelphia: The University of Pennsylvania Press, 2012), 179.

${ }^{3}$ On a brief overview of the Civil Rights Movement, see Robert O. Self, "Negro Leadership and Negro Money": African American Political Organizing in Oakland before the Panthers," in Freedom North: Black Freedom Struggles Outside the South, 1940-1980, ed. Jeanne F. Theoharis and Komozi Woodard (New York: Palgrave Macmillan, 2003), 94.

${ }^{4}$ In After the Rebellion: Black Youth, Social Movement Activism, and the Post-Civil Rights Generation, Sekou Franklin writes that in social movements, activists possess "different political orientations and positions within the social and political structure, [and] it is often the case that competing claims will emerge among activists who share the same political grievances." Sekou M. Franklin, After the Rebellion: Black Youth, Social Movement Activism, and the Post-Civil Rights Generation (New York: New York University Press, 2014), 31.

${ }^{5}$ See Peter B. Levy, Civil War on Race Street: The Civil Rights Movement in Cambridge, Maryland (Gainesville: University Press of Florida, 2003), 6.
} 
have demonstrated that rather than one singular crusade situated in the South and constricted to a roughly fourteen-year period (1954 1968), grassroots movements that emerged across the United States over several decades comprised the larger movement. Though scholars recognize that 1954-1968 constitutes the "classical" or modern period, the period from the 1930s to the passage of Brown v. Board of Education (1954), the Supreme Court case that banned the segregation of public schools and overturned the "Separate-but-Equal" doctrine, constitutes the early period. ${ }^{6}$

Scholarly works proliferate that demonstrate that "the black freedom struggle had its roots and branches in the 1930s and 1940s. This activism was not merely a dress rehearsal but a crucial birthplace and battleground for the mass movement that flowered in the 1960s." " Understanding the ways in which African Americans fought for economic, political, social, and civil rights during the early period is of particular importance given that activists did not have the benefit of Brown. In other words, before

\footnotetext{
${ }^{6}$ The following texts are a selection of monographs that focus on the Civil Rights Movement outside the South: Martha Biondi, To Stand and Fight: The Struggle for Civil Rights in Postwar New York City (Cambridge: Harvard University Press, 2006); Matthew J. Countryman, Up South: Civil Rights and Black Power in Philadelphia (Philadelphia: University of Pennsylvania Press, 2007); Gretchen Cassel Eick, Dissent in Wichita: The Civil Rights Movement in the Midwest, 1954-72 (Champaign: University of Illinois Press, 2007); Patrick D. Jones, The Selma of the North: Civil Rights Insurgency in Milwaukee (Cambridge: Harvard University Press, 2010); Dwayne A. Mack, Black Spokane: The Civil Rights Struggle in the Inland Northwest (Norman: University of Oklahoma Press, 2014); Matthew C. Whitaker, Race Work: The Rise of Civil Rights in the Urban West (Lincoln: University of Nebraska Press, 2007). There is also a small body of scholarship on the Civil Rights Movement in the Border States-Fosl and K'Meyer, Freedom on the Border; K'Meyer, Civil Rights in the Gateway to the South; Clarence Lang, Grassroots at the Gateway: Class Politics \& Black Freedom Struggle in St. Louis, 1936-75 (Ann Arbor: University of Michigan Press, 2009); Clarence Lang, "Locating the Civil Rights Movement: An Essay on the Deep South, the Midwest, and Border South in Black Freedom Studies," Journal of Social History 47, no. 2 (2013): 371-400. Levy, Civil War on Race Street. A good starting point for examining local movements is Theoharis and Woodard, Freedom North and Jeanne Theoharis and Komozi Woodard, eds., Groundwork: Local Black Freedom Movements in America (New York: NYU Press, 2005). These sources acknowledge that smaller grassroots movements comprised the larger civil rights struggleAldon Morris, The Origins of the Civil Rights Movement: Black Communities Organizing for Change (New York: The Free Press, 1984), 40; J. Todd Moye, "Focusing Our Eyes on the Prize: How Community Studies are Reframing and Rewriting the History of the Civil Rights Movement," in Civil Rights History from the Ground Up: Local Struggles, a National Movement, ed. Emilye Crosby (Athens: University of Georgia Press, 2011), 148. Civil rights activist Bayard Rustin deemed the 1954-1965 period of the Civil Rights Movement as "classical." Bayard Rustin, Down the Color Line: The Collected Writings of Bayard Rustin (Chicago: Quadrangle Books, 1971), 111.

${ }^{7}$ See Theoharis and Woodard, Freedom North, 11.
} 
NAACP attorneys arguing Brown v. Board of Education (1954) reversed Plessy v.

Ferguson (1896), black people were agitating for rights during a time period when segregation and discrimination were still sanctioned by law. Though operating under a legalized racial hierarchy, African Americans fought to secure economic, political, social, and civil rights between 1930 and $1954 .^{8}$

During this time period, a number of organizations representing the varying political grievances of African Americans worked to dismantle white supremacy. The NAACP was once such organization. Since its founding in 1909 by a group of African American intellectuals and progressive whites, the NAACP fought to secure civil and political rights for African Americans through "investigation, publicity, legal aid, and public meetings." ${ }^{9}$ While the NAACP has arguably been at the vanguard of social change from the Nadir of the Negro to the Obama era, a surprisingly small body of scholarship exists on the organization that assesses its importance to the black freedom struggle.

One reason why scholarship on the NAACP remains limited is public perception of the NAACP as an organization comprised of middle-class African Americans beholden to the politics of respectability and civility for securing social change. Juxtaposed alongside other organizations active during the early period that were more radical in their approach and possessed a higher composition of the black working class,

\footnotetext{
${ }^{8}$ Some of the seminal works that focus on the early period of the civil rights struggle include, Beth Tompkins Bates, Pullman Porters and the Rise of Protest Politics in Black America, 1925-1945 (Chapel Hill: The University of North Carolina Press, 2001); Erik S. Gellman, Death Blow to Jim Crow: The National Negro Congress and the Rise of Militant Civil Rights (Chapel Hill: The University of North Carolina Press, 2003); Glenda Gilmore, Defying Dixie: The Radical Roots of Civil Rights, 1919-1950 (New York: W.W. Norton \& Company, 2008); Jacquelyn Dowd Hall "The Long Civil Rights Movement and the Political Uses of the Past," The Journal of American History 91, no. 4 (2005): 1233-1263; Robin D.G. Kelley, Hammer and Hoe: Alabama Communists During the Great Depression (Chapel Hill: The University of North Carolina Press, 1990); Robert Korstad, Civil Rights Unionism: Tobacco Workers and the Struggle for Democracy in the Mid-Twentieth-Century South (Chapel Hill: The University of North Carolina Press, 2003).

${ }^{9}$ Patricia Sullivan, Lift Every Voice: The NAACP and the Making of the Civil Rights Movement (New York: The New Press, 2009), 16.
} 
this stereotype appears to hold true. Regardless of the pervasive stereotype, scholars such as Minnie Finch and Patricia Sullivan credit the NAACP for producing one of the most significant contributions to the black freedom struggle, the passage of Brown v. Board of Education (1954), which overturned Plessy v. Ferguson (1896). ${ }^{10}$

Scholars of the NAACP have recognized that during the early period of the Civil Rights Movement, the NAACP's greatest gains occurred in laying the groundwork for Brown. What they have tended to underemphasize, however, is the significance of social location in producing Brown. For the NAACP and its attorneys who believed "that change must come first to the border states before the Deep South could be breached," the border served as tactical ground in pursuit of the 1954 victory. Border states were an ideal testing ground because white supremacy, specifically segregation practices, was identical to other areas of the South. But access to the ballot and the presence and visibility of white allies, both characteristics mirroring the Northeast and Midwest, allowed the Border States to produce a more progressive civil rights struggle than did cities located farther south. With its focus on Baltimore, historian Lee Sartain's Borders of Equality: The NAACP and the Baltimore Civil Rights Struggle, 1914-1970, serves as the seminal text interrogating the work of the NAACP in the border region. Sartain also devotes a chapter in Borders of Equality to examining how the NAACP Youth Council in Charm City helped to dismantle Jim Crow, granting attention to the Association's youth arm, which, until most recently, had not been subjected to scholarly inquiry. ${ }^{11}$

\footnotetext{
${ }^{10}$ Minnie Finch, The NAACP: Its Fight for Justice (New Jersey: The Scarecrow Press, Inc., 1981); Sullivan, Lift Every Voice.

${ }^{11}$ Historian John Dittmer writes that the NAACP breached the Border States before the Deep South states. John Dittmer, Local People: The Struggle for Civil Rights in Mississippi (Champaign: University of Illinois Press, 1994), 29. The following texts document the civil rights struggle in the Border States: Fosl and K'Meyer, Freedom in the Border; K'Meyer, Civil Rights in the Gateway to the South; Lang, Grassroots at the Gateway; Lang, "Locating the
} 
In 2013, historian Thomas Bynum published the first text documenting the history of NAACP youth groups and their contribution to the black freedom struggle in NAACP Youth and the Fight for Black Freedom, 1936-1965. Until Bynum's publication, the body of scholarship on the NAACP focused solely on the role of adults. In demonstrating that NAACP youth chose to confront racism and racial inequality head-on, Bynum's work challenges prior scholarship on the Association and commonly held beliefs that the NAACP chose only to work through the courts and utilize the politics of civility to secure social change. NAACP youth, by rallying for social change through marches, protests, and sit-ins, augmented the work of adult branches with more militant tactics, thereby engaging in a type of civic engagement political scientist Holloway Sparks terms "dissident citizenship."12

Additionally, the absence of NAACP youth groups in the Association's narrative is part of a larger trend of obscuring the activism of black youth that took place during the early period of the Civil Rights Movement. Ibram Kendi (2012), in The Black Campus Movement: Black Students and the Racial Reconstitution of Higher Education, 1965-1972, explains: “...[I]n the growing historiography of the formative years of the CRM, black students are rarely brought to light. Instead, New Dealers, community activists, populist politicians, Communists, unionists, anti-colonialists, NAACP and NNC

Civil Rights Movement;" Levy, Civil War on Race Street. Historian Lee Sartain writes on the NAACP's activism in Baltimore, Maryland. Sartain, Borders of Equality.

12 Thomas Bynum, NAACP Youth and the Fight for Black Freedom, 1936-1965 (Knoxville: The University of Tennessee Press, 2013). Sparks defines dissident citizenship as "the practices of marginalized citizens who publicly contest prevailing arrangements of power by means of oppositional democratic practices that augment or replace institutionalized channels of democratic opposition when those channels are inadequate or unavailable. Instead of voting, lobbying, or petitioning, dissident citizens constitute alternative public spaces through practices such as marches, protest, and picket lines; sit-ins, slow-downs, and cleanups; speeches, strikes, and street theatre. Dissident citizenship...encompasses the often creative oppositional practices of citizens who, either by choice (or much more commonly) by forced exclusion from the institutionalized means of opposition, contest current arrangements of power from the margins of the polity." Holloway Sparks, "Dissident Citizenship: Democratic Theory, Political Courage, and Activist Women," Citizenship in Feminism: Identity, Action, and Locale 12, no 4 (1997): 75. 
members, and labor organizers are some of the groups often situated at the starting line in the late 1930s.",

As this thesis will show, however, African American youth were also affected by racism and racial inequality, and secured their rightful place in the fight for freedom and democracy. While the central focus of this thesis is to narrate the history of the Louisville NAACP youth groups from 1937 until 1955, it brings to bear many of the prevailing issues in civil rights scholarship, including black youth activism during the early period of the Civil Rights Movement, the role of the NAACP in the black freedom struggle, and how social location impacts social movements. While there are several different factors at play, this thesis investigates them as a collective issue, by posing the questions: What do the activities of the Louisville chapter of the NAACP youth groups between 1937 and 1955 reveal about black youth activism that occurred prior to the classical period of the Civil Rights Movement? and What does NAACP youth groups' activism in Louisville reveal about the Civil Rights Movement in the border region?

\section{METHODOLOGY}

To answer the research questions, I first had to unearth the Louisville youth's activities by examining the archival record of the NAACP. The Papers of the NAACP, located in Black Studies Research Sources, an online repository of numerous papers, files, and records documenting the black freedom struggle, hold the documents of countless NAACP branches across the country. The Papers of the NAACP are composed of 30 parts organized around a particular campaign, theme, or subject. Each part is further

\footnotetext{
${ }^{13}$ Ibram Kendi, The Black Campus Movement: Black Students and the Racial Reconstitution of Higher Education, 1965-1972 (New York: Palgrave Macmillan, 2012), 49.
} 
organized by series. As the documents contained in the Black Studies Research Sources are digitized, the Papers of the NAACP are stored on microfilm.

I selected microfilm from Part 19, Series A, B, and C because they document the activities of NAACP youth groups between 1919 and 1955. In addition, because Louisville is a southern border city, I selected microfilm from Part 26, Series A because it documents the activities of the adult branches of the Southern conferences between 1940 and 1955. Furthermore, I selected microfilm from Part 12, Series A because it documents the activities of the adult branches of the Southern conferences between 1913 and 1939. Frames selected in Parts 19, 26 and 12 specifically contain information on the NAACP youth groups in Louisville.

First, I retrieved Part 19, Series A, which contains the general files of the youth division. Next, I retrieved Series B of Part 19. Series B documents (beginning with the American Jewish Congress and ending with the Motion Picture Project) the activities youth councils and college chapters embarked upon to fulfill their mission as delineated in the 1943 constitution. Because Series B did not contain the activities of the Louisville Youth between 1940 and 1955, I retrieved Series C of Part 19.

Series $\mathrm{C}$ is the continuation of Series B, documenting the activities (beginning with NAACP Dance ["N"] and ending with Youthbuilders ["Y"]) youth councils and college chapters embarked upon to fulfill their mission as delineated in the 1943 constitution. Although Muriel Gregg, who would be instrumental in reorganizing the Louisville Youth Council in 1955, is listed in select activities of 1955, Series C did not contain the activities of the Louisville youth groups between 1940 and 1955. 
Because Series B and C did not provide information on the activities of Louisville's youth groups between 1940 and 1955, I retrieved Part 26, Series A to determine if the adult branch of the Louisville NAACP documented the activities of its youth arm between 1940 and 1955. Finally, because Part 26 documents the activities of the youth groups between 1940 and 1955, I retrieved Part 12, Series A to determine if the Louisville adult branch documented the activities of its youth arm between 1937 and 1939. (See table 1) 
Table 1

\begin{tabular}{|c|c|c|c|c|c|}
\hline Sample & $\begin{array}{l}\text { General } \\
\text { Editors }\end{array}$ & Frame & \begin{tabular}{|c|}
$\begin{array}{l}\text { Location \& } \\
\text { Title }\end{array}$ \\
\end{tabular} & Major Topics & Missing Data \\
\hline $\begin{array}{l}\text { Part 19: Youth File, } \\
\text { Series A: 1919-1939 }\end{array}$ & $\begin{array}{l}\text { John H. } \\
\text { Bracey, Jr. } \\
\text { and August } \\
\text { Meier }\end{array}$ & 0027 & \begin{tabular}{|l|} 
Reel 4, \\
Group I, Box \\
E-3 \\
Youth \\
Council- \\
Kentucky, \\
1937-1939
\end{tabular} & $\begin{array}{l}\text { Charter applications from Louisville; Louisville Council } \\
\text { activities, antilynching demonstrations, and membership } \\
\text { campaign }\end{array}$ & \\
\hline \multirow[t]{2}{*}{$\begin{array}{l}\text { Part 19: Youth File, } \\
\text { Series B: 1940-1955, } \\
\text { American Jewish } \\
\text { Congress-Motion } \\
\text { Picture Project }\end{array}$} & $\begin{array}{l}\text { John H. } \\
\text { Bracey, Jr. } \\
\text { and August } \\
\text { Meier }\end{array}$ & 0683 & \begin{tabular}{|} 
Reel 14, \\
Group II, \\
Box E-19 \\
Gregg, \\
Muriel, \\
March-July \\
1955 \\
\end{tabular} & $\begin{array}{l}\text { Appointment as youth field secretary; work assignments; } \\
\text { speaking engagements; travel itineraries; monthly reports; } \\
\text { tours of Pennsylvania, West Virginia, and Kentucky youth } \\
\text { councils and college chapters; Philadelphia youth council } \\
\text { reactivation project. }\end{array}$ & $\begin{array}{l}\text { Activities of } \\
\text { Louisville } \\
\text { Youth Council } \\
\text { between } 1940 \\
\text { and } 1955\end{array}$ \\
\hline & & 0818 & $\begin{array}{l}\text { Reel 14, } \\
\text { Group II, } \\
\text { Box E19, } \\
\text { Gregg, } \\
\text { Muriel, } \\
\text { August-- } \\
\text { November } \\
1955 . \\
\end{array}$ & $\begin{array}{l}\text { Expenses; reorganization of Louisville, Kentucky, youth } \\
\text { council; travel itineraries; work assignments; youth } \\
\text { membership campaign; resignation; report of tour of West } \\
\text { Virginia and Kentucky youth councils and college chapters. }\end{array}$ & $\begin{array}{l}\text { Activities of } \\
\text { Louisville } \\
\text { Youth Council } \\
\text { between } 1940 \\
\text { and } 1955\end{array}$ \\
\hline $\begin{array}{l}\text { Part 19: Youth File, } \\
\text { Series C: 1940- } \\
\text { 1955-Youthbuilders }\end{array}$ & $\begin{array}{l}\text { John H. } \\
\text { Bracey, Jr. } \\
\text { and August } \\
\text { Meier }\end{array}$ & & $* * * * * * *$ & $* * * * * * *$ & \begin{tabular}{|} 
Activities of \\
Louisville \\
Youth Council \\
between 1940 \\
and 1955 \\
\end{tabular} \\
\hline \multirow[t]{3}{*}{$\begin{array}{l}\text { Part 26: Selected } \\
\text { Branch Files, 1940-- } \\
\text { 1955, Series A: The } \\
\text { South }\end{array}$} & $\begin{array}{l}\text { John H. } \\
\text { Bracey, Jr., } \\
\text { Sharon } \\
\text { Harley, and } \\
\text { August } \\
\text { Meier }\end{array}$ & 0399 & $\begin{array}{l}\text { Reel 11, } \\
\text { Group II, } \\
\text { Box C-66 } \\
\text { Louisville } \\
\text { Kentucky, } \\
\text { 1940-1944 } \\
\end{array}$ & $\begin{array}{l}\text { Memberships; Chicago Council of Negro Organizations; } \\
\text { restrictive covenants; finances; youth council }\end{array}$ & \\
\hline & & 0586 & \begin{tabular}{|c|} 
Reel 11, \\
Group II, \\
Box C-66 \\
Louisville, \\
Kentucky, \\
$1945-1949$ \\
\end{tabular} & \begin{tabular}{|} 
West End youth council; poems by Patricia Lauderdale; \\
membership campaign; opposition to Boswell amendment to \\
Alabama constitution; veterans committee; campaign for \\
admission of African Americans to Kentucky graduate and \\
professional schools; protest of segregated seating at \\
showing of Carmen Jones, newsletter; NAACP opposition \\
to Mundt Bill (H.R. 5852) \\
\end{tabular} & \\
\hline & & 0841 & $\begin{array}{l}\text { Reel 11, } \\
\text { Group II, } \\
\text { Box C-67 } \\
\text { Louisville, } \\
\text { Kentucky, } \\
1950-1955\end{array}$ & $\begin{array}{l}\text { Secretary's report (1949) covering mass meetings, } \\
\text { education, legal redress, youth council, membership, and } \\
\text { finances; complaints filed by Charles J. Lunderman Jr. } \\
\text { regarding branch president R. Everett Ray and related } \\
\text { correspondence; statement by Stephen Gill Spottswood } \\
\text { regarding police brutality in Louisville; debate on adoption } \\
\text { of anticommunist oath for branch executive board members; } \\
\text { reaction to Brown v. Board of Education decision; literature } \\
\text { seized from home of Carl and Anne Braden; finances } \\
\end{array}$ & \\
\hline $\begin{array}{l}\text { Part 12: Selected } \\
\text { Branch Files, 1913-- } \\
\text { 1939, Series A: The } \\
\text { South }\end{array}$ & $\begin{array}{l}\text { John H. } \\
\text { Bracey, Jr. } \\
\text { and August } \\
\text { Meier }\end{array}$ & 1054 & \begin{tabular}{|c|} 
Reel 12, \\
Group 1, Box \\
G-77 \\
October- \\
December \\
1937 \\
\end{tabular} & $\begin{array}{l}\text { Youth Council; college chapter; antilynching; Daisy } \\
\text { Lampkin visit; Rep. Fred Vinson background; Madame C.J. } \\
\text { Walker Co. employees; teachers' salaries case; criminal } \\
\text { justice; employment discrimination (department store) }\end{array}$ & \\
\hline
\end{tabular}


To fully construct the story of the Louisville NAACP youth groups, I also utilized The Louisville Leader and The Crisis. The Louisville Leader, in circulation from 1919 until 1950, was one of three newspapers published for Black Louisvillians. It was useful in locating the publicized activities of the NAACP youth undocumented in the archives. Similarly, The Crisis, the NAACP's official magazine, was also useful in locating activities of the youth that were not found in the archives. I also referenced a master's thesis that documents the civil rights activities of the Louisville (adult) NAACP between 1914 and 1960 as a means to provide context for the civil rights issues in Louisville during each time period in which the Louisville NAACP youth were active. ${ }^{14}$ The information contained in the Papers of the NAACP, The Louisville Leader, and The Crisis was utilized to construct a narrative of the Louisville NAACP youth groups from 1937 until 1955.

\section{LIMITATIONS TO THE STUDY}

Several limitations existed in constructing this narrative. First, it proved difficult to organize the archival information. While organized by time period, much of the information was not organized in a sequential manner. In addition, while the Papers of the NAACP are valuable in that the NAACP required its local branches to keep a record of its members and activities, they are limited insofar as they reveal only what members of the Louisville adult branch chose to chronicle.

\footnotetext{
${ }^{14}$ The Louisville Defender and Louisville News were the other newspapers published for African Americans. The Louisville Leader, according to John E. Kleber, "implored African Americans to vote, opposed Jim Crow laws and black allegiance to the Republican Party, and deplored lynching. I. Willis Cole, the founder of The Leader, publicized discrimination against blacks, especially by businesses, and encouraged African Americans to boycott white-owned businesses." "Louisville Leader" in The Encyclopedia of Louisville, ed. John E. Kleber (Lexington: The University Press of Kentucky, 2001), 557.
} 
As a consequence, the impetus behind many of the youth groups' activities are unknown (such as why a youth arm was initially organized), and there are several instances when insufficient evidence existed to determine whether youth groups were active for given periods of time. Furthermore, there are several individuals whose names are provided, but information that would have further identified them is not provided. Moreover, because in Louisville the adult branch kept a record of the youth groups' activities from 1940 - 1955, it was at the discretion of the adults, and not the youth, which activities were publicized. Where the archives lacked information, I utilized The Louisville Leader and The Crisis. There were several instances that these sources provided vital information not contained in the archives, which helped to construct a more coherent narrative. Yet because of the time period examined, several issues of both the newspaper and the NAACP's magazine are missing or no longer accessible.

\section{ORGANIZATION OF STUDY}

This thesis is organized in the manner in which the Papers of the NAACP is organized. Chapter two focuses on the Louisville youth groups' activism from 1937 until 1939. Chapter three examines their activities in the interwar years, 1940-1944. Chapter four focuses on their work from 1945 until 1955. Although the archives are arranged from 1945-1949 and 1950 - 1955, a lack of evidence does not make it possible to conclude whether the Louisville youth were active from 1950 - 1955, necessitating that this timeframe is included under their activism from 1945-1949. Chapter five discusses the work of the Louisville NAACP youth from 1937 until 1955 and offers some analysis and new directions for research. 


\title{
CHAPTER II
}

\author{
"WE MUST ACT-AND ACT NOW"15: \\ LOUISVILLE NAACP YOUTH, 1937-1939
}

Because "[o]ne of the greatest weaknesses of the Association's program [was] the lack of a definite program for activity by the junior braches and younger people," the National Association for the Advancement of Colored People (NAACP), America's premiere civil rights organization, instituted a national youth and college division in 1936. ${ }^{16}$ The national office granted Juanita Jackson, a Baltimore native and former youth activist, directorship of the division. When Jackson assumed her position, she abolished the junior branches, which had an age bracket of $14-21$, and reorganized the youth arm into junior youth councils, youth councils, and college chapters in order to draw greater numbers of youth to the association. ${ }^{17}$

Youth aged $12-15$ comprised the junior youth councils; youth aged $16-25$ comprised the youth councils, and students aged 16-25, but enrolled in a college or university, comprised the college chapters. In their governing framework, youth groups

${ }^{15}$ Juanita Jackson, as quoted in Bynum, NAACP Youth, 15.

${ }^{16}$ NAACP Executive Secretary Walter White, as quoted in Bynum, NAACP Youth, 2.

${ }^{17}$ Ibid, 2. Junior branches and college chapters existed prior to the NAACP's board of directors' call for the reorganization of the youth division in 1935, but according to Bynum, they were "poorly organized and understaffed, lacked sufficient funding, and had no nationally coordinated youth agenda." On Jackson's background and appointment as director of the national youth and college division see Bynum, NAACP Youth, 2-6. 
elected a president, vice president, secretary, assistant secretary, and treasurer, thus modeling the organization of the Association's adult branches. The youth groups were open to youth of all races, social classes, and religious beliefs. Jackson enacted a political agenda, mirroring that of the national NAACP, centered on anti-lynching legislation, civil liberties, and equal opportunity in education and in employment, and local NAACP youth groups followed this agenda. ${ }^{18}$

On the second level, the youth division followed the platform (anti-lynching, civil liberties, equal educational and employment opportunities) of the national office. With the exception of the anti-lynching campaign, which a vast majority of youth groups supported given its importance to the fight against lynching by the national office, local NAACP youth branches enacted other parts of the platform more suited to local issues. When youth decided upon their political agenda, they worked with their supervisor (or advisor), a member of the adult branch, to implement programming or events. Subsequently, the youth groups obtained permission from the executive committee of the local adult branch (on which the president of the youth council sat) to execute the programming. Thus the political work of the NAACP youth groups was bounded at two levels - by following the agenda of the national office, and by having to obtain consent from the adult branch to enact its agenda. It is important to note that college chapters received permission from the national NAACP board of directors as well as college administrators of the colleges they attended to implement their programs. ${ }^{19}$

From its inception until 1939, the NAACP Youth Council in Louisville implemented programs to build and sustain the organization, and enacted an agenda

\footnotetext{
${ }^{18}$ Ibid, 5-6.

${ }^{19}$ Ibid.
} 
focused on anti-lynching and anti-militarism. A youth council and a college chapter at Louisville Municipal College existed during this time period, both of which were located in Louisville's West End, the area of the city where the majority of African Americans resided between 1900 and 1946. It is unclear of the ages of the founding members of the Louisville junior branch, given the fact that they formed as a junior branch, as opposed to a junior youth council or a youth council.

While only one member of the local adult branch was required to supervise/advise the youth council, at the time of its inception, the Louisville youth council had four advisors. Two of the four advisors were teachers. According to Lee Sartain in Invisible Activists: Women of the Louisiana NAACP and the Struggle for Civil Rights, 19151945, "The NAACP saw teachers as leaders that could instill black youth with racial pride and an integrationist vision of U.S. society, or at least argue for equality within the current segregated system." Teachers were ideal for recruiting their students to become members of NAACP youth councils, and as a natural extension of their role, supervised youth councils. ${ }^{20}$ The Louisville youth council also had two sponsors, who were members of the adult branch. It is unclear whether the Louisville NAACP, in organizing its youth council, made a distinction between sponsorships and supervisors/advisors.

On Thursday, September 30, 1937, twenty-two youth from Louisville, Kentucky's West End met to establish a junior branch of the NAACP. Dr. T.R. Spillman and Mrs. Penelope Adams, both members of the adult branch, sponsored the event, at which three young women, Jessie Duncan, Marion Williams, and Mildred Ferrell, and one young man, Rufus Stocks, were elected as president, vice president, secretary, and treasurer,

\footnotetext{
${ }^{20}$ Lee Sartain, Invisible Activists: Women of the Louisiana NAACP and the Struggle for Civil Rights, 1915 1945 (Baton Rouge: Louisiana, 2007), 91-92.
} 
respectively. Four adults, Miss Mae F. Carroll, Miss Virginia Gatliff, Miss Geraldine Narfield, and Miss Nomia Jetton, also attended the meeting. Gatliff and Jetton taught in the local schools. ${ }^{21}$

The following month, in October, Robert Purday united a group of fifteen students from the Louisville Municipal College (LMC), located on Seventh and Kentucky, and organized a college chapter of the Louisville NAACP. One of three liberal arts colleges in the country established for African Americans, LMC served as the African American division of the University of Louisville, a public university established in $1798 .^{22}$

By the end of October, the junior branch, which hosted a meeting every week at the Phyllis Wheatley branch of the YWCA, successfully recruited twenty-eight members, allowing them to secure an official charter from the NAACP's national office just short of the Thanksgiving holiday on November 17, $1937 .{ }^{23}$ Encouraged by Juanita Jackson,

\footnotetext{
${ }^{21}$ The twenty-two youth were: Jessie Duncan, Marion Williams, Mildred Terrell, Rufus Stocks, Winifred Logan, Elizabeth Shelton, Carrie Mae Smith, Harryetta Reynolds, Bernice Newton, Susie Mae Wilson, Odessa Ward, Doris Clark, Sylvia Wilson, Marjorie Bryant, Monroe Harris, Warren Alexander, Julius Swafford, Andrew Wade, William Ratliff, Earl N. Berry, Maude Ella Perry, James F. Condell-Application for Charter, Papers of the NAACP, Part 19: Youth File, Series A: 1919-1939, Reel 4, Group I, Box E-3, Frame 0027, Youth Council-Kentucky, $1937-$ 1939, Black Studies Research Sources. Letter from Jessie Duncan to Juanita Jackson on the election of the junior branch's officers, December (?), 1937, Papers of the NAACP, Part 19: Youth File, Series A: 1919-1939, Reel 4, Group I, Box E-3, Frame 0027, Youth Council-Kentucky, 1937-1939, Black Studies Research Sources. According to Bynum, NAACP Youth, 6, the president represented the youth during monthly meetings of the adult branch and also served on the executive committee of the local branch, alongside two additional members of the youth group, in order to promote participation and collaboration between the youth and adults.

${ }^{22}$ Letter from special assistant to the secretary to Robert Purday on the organization of a college chapter at Louisville Municipal College, October 26, 1937. Papers of the NAACP, Part 12: Selected Branch Files, 1913-1939, Series A: The South, Reel 12, Group I, Box G-77, Frame 1054, October-December 1937, Black Studies Research Sources. "Louisville Municipal College," in The Encyclopedia of Louisville, ed. John E. Kleber (Lexington: The University Press of Kentucky, 2001), 562.

${ }^{23}$ The Phillis Wheatley Branch, founded in the early 1920s, and closed during the 1970s, served African Americans. "YWCA (Louisville, KY)," accessed May 17, 2015, http://nkaa.uky.edu/record.php?note_id=1696. According to Bynum, NAACP Youth, 5, at least twenty-five members were required to officially establish a junior council, youth council, or college chapter.
} 
national director of the NAACP youth division, the Louisville junior branch immediately sprung into action.

To foster camaraderie amongst its members and to encourage more youth to join, the junior branch, between the beginning of fall and continuing through the start of the holiday season, hosted several social events such as popularity contests, candy-pulling contests, teas, bazaars, and musical programs. In December, the junior branch launched its first Christmas Seal Sale, selecting Thomas Wright as chair. That same month, the Youth also organized a series of minstrels to finance one of their first big events, a dance held at the Allen hotel, which served African Americans, on December $16^{24}$

The launching of the youth branch in Louisville took place during a time when the senior branch of the Louisville NAACP had been active for 23 years, having won the NAACP one its first and most significant legal victories in 1917, when the Supreme Court ruled in Buchanan v. Warley that local ordinances requiring racial segregation in housing violated the Equal Protection Clause of the Fourteenth Amendment. During the late 1930s, the adult branch confronted the most pressing issues facing black people in Louisville, inequities in education and a lack of access to public accommodations.

Between 1937 and 1939, the Louisville adult branch utilized strategies such as issuing petitions, filing lawsuits, and evoking the court of public opinion to secure equal

${ }^{24}$ Letter from Mildred Ferrell to Juanita Jackson on fall programs, October 29, 1937, Papers of the NAACP, Part 19: Youth File, Series A: 1919-1939, Reel 4, Group I, Box E-3, Frame 0027, Youth Council—Kentucky, 19371939, Black Studies Research Sources. Letter from Jessie Duncan to Juanita Jackson, December (?), 1937, Papers of the NAACP, Part 19: Youth File, Series A: 1919-1939, Reel 4, Group I, Box E-3, Frame 0027, Youth CouncilKentucky, 1937-1939, Black Studies Research Sources. Letter from Jessie Duncan to Juanita Jackson on Christmas Seal Sale, December 8, 1937, Papers of the NAACP, Part 19: Youth File, Series A: 1919-1939, Reel 4, Group I, Box E3, Frame 0027, Youth Council-Kentucky, 1937-1939, Black Studies Research Sources. Letter from Jessie Duncan to Juanita Jackson on dance at the Allen Hotel, December (?), 1937, Papers of the NAACP, Part 19: Youth File, Series A: 1919-1939, Reel 4, Group I, Box E-3, Frame 0027, Youth Council-Kentucky, 1937-1939, Black Studies Research Sources. According to John Kleber, Black Louisvillians and visitors to the city had to patronize the Allen hotel, owned by B.W.P. Allen, an African American insurance agent, because white hotels in Louisville either refused service or offered limited service to African Americans during the Jim Crow years. "Hotels and Motels," in The Encyclopedia of Louisville, ed. John E. Kleber (Lexington: The University Press of Kentucky, 2001), 405. 
pay for black teachers in the city, to initiate their efforts to integrate the University of Kentucky, and to continue their efforts to integrate public parks and libraries. ${ }^{25}$ While the adults fought to secure equality in education and public accommodations, the focus of the Louisville youth, in the decade's closing years, was different. Instead, the youth focused specifically on bringing awareness to lynching and mob violence and protesting rising militarism, and were encouraged to do so by the adult branch.

At the start of 1938, the national office praised the Louisville junior branch for its social activities and fundraising campaigns sponsored in its formative months, but they were encouraged to initiate a series of discussions on the problem of lynching. The national NAACP's Special Assistant to the Secretary sent President Duncan a Guide for the 'Study and Discussion of Lynching,' commissioned by African American anthropologist John Gibbs St. Clair Drake, who also served as chairman of the NAACP's Anti-Lynching Planning Committee. NAACP youth across the United States were gearing up for another series of anti-lynching demonstrations in February, the month in which youth groups held the National Youth Demonstration Against Lynching. ${ }^{26}$

Since established in 1909, the NAACP's fight against lynching and mob violence had been a "motivating force behind the Association's work." 27 The NAACP employed a number of strategies to help eradicate acts of racial terror, including massive campaigns publicizing the horrors of racial violence, but their most concentrated effort involved

\footnotetext{
${ }^{25}$ On Louisville NAACP's work for teacher equalization pay, see McElhone, Civil Rights Activities, 81-84; on University of Kentucky integration, Ibid, 96-97; on open accommodations (libraries and parks), Ibid, 150.

${ }^{26}$ According to Bynum, NAACP Youth, 8, February 12 was selected as the date of the first national youth demonstration because it was the birthday of Abraham Lincoln, who "symbolized a spirit of freedom and democracy." February was also the birth month of Frederick Douglass and George Washington.

${ }^{27}$ Charles Flint Kellogg, NAACP: A History of the National Association for the Advancement of Colored People: Volume I (Baltimore: The John Hopkins Press, 1967), 57.
} 
laboring for passage of a federal anti-lynching bill. In 1934, Democratic senators Edward Costigan (Colorado) and Robert Wagner (New York) crafted the Costigan-Wagner AntiLynching Bill. The Senate Judiciary Committee voted for passage of the bill, but southern senators, who maintained that passage of the bill would violate states' right to resolve lynching, blocked its passage. By 1937, supporters reintroduced the bill in each congressional session. That same year, youth groups across the nation made support of the bill their first national campaign. By 1938, NAACP youth sponsored demonstrations against lynching in 78 cities across the United States. ${ }^{28}$

In Louisville, with Drake's guide in hand, the young women leaders and young male treasurer met with Purday and other students from the college chapter at the end of January to "launch all plans for the campaign." The executive boards from the youth council and college chapter decided upon a free program to be held one day before Valentine's Day. The students selected West Chestnut Street Baptist Church as the location for the event. As one of the most socially active black churches in Louisville, West Chestnut Street Baptist proved the ideal setting. The Louisville youth had all intentions to make the event a grand occasion, having secured the "confidence and cooperation of practically every well known organization...including [the] Senior Branch of the N.A.A.C.P" and "several distinguished speakers," and having sparked the interest of a prominent white individual "who seem[ed] rather invested in the welfare of the Negro race. ${ }^{29}$

\footnotetext{
${ }^{28}$ See Bynum, NAACP Youth, 7 for a brief history of the national office's work for a federal anti-lynching bill during the 1930s. Ibid, 8 for examples on other NAACP youth groups' work against lynching.

${ }^{29}$ Letter from Jessie Duncan and Mildred Terrell to Juanita Jackson on plans for anti-lynching demonstration, February 3, 1938, Papers of the NAACP, Part 19: Youth File, Series A: 1919-1939, Reel 4, Group I, Box E-3, Frame 0027, Youth Council-Kentucky, 1937-1939, Black Studies Research Sources; "Mass Meeting," The Louisville Leader (Louisville, KY), Feb. 5, 1938.
} 
On Sunday, February 13, Black Louisvillians from all walks of life began arriving at 6:30 p.m. at West Chestnut Street Baptist to attend Louisville's Youth Council Mass Demonstration, sponsored by the NAACP adult advisors to the youth council. As the seats began to fill, the youth handed out copies of the Negro National Anthem, courtesy of an art print shop recently opened. Shortly after 7 p.m., the congregation, which filled every seat, stood and joined together in singing "Lift Every Voice and Sing." Rev.

William Johnson, pastor of West Chestnut, blessed the service, and then called upon the church's Glee Club to provide the audience with a musical selection. After regaling the audience, the Glee Club took their seats, and attorney A.J. Slaughter introduced the speakers, Mr. Paul J. Kellogg, Col. J.H. Bowles, and Mr. Paul Dunbar. ${ }^{30}$

Kellogg, a white resident of 910 South $5^{\text {th }}$ Street, and a presumed member of the American Communist Party (CP), ${ }^{31}$ brought the "audience to its feet with his wonderful speech. His most outstanding point was [that] the Southern Senators who oppose the passage of the anti-lynching bill are not representative of the south since they are elected by a minority, rather than the majority." Kellogg also proclaimed, "These senators preach Hitler's doctrine!"32

\footnotetext{
${ }^{30}$ Letter from Jessie Duncan and Corrine Williams to Juanita Jackson detailing the anti-lynching program, March 2(?), 1938, Papers of the NAACP, Part 19: Youth File, Series A: 1919-1939, Reel 4, Group I, Box E-3, Frame 0027, Youth Council-Kentucky, 1937-1939, Black Studies Research Sources. At some unknown point, the Louisville youth changed their title from junior branch to youth council.

${ }^{31}$ Information on Kellogg obtained from Committee On Un-American Activities, Nominating Petitions for 1940 Elections Under the Title and Designation of Communist Party, various States: Official Report Prepared by and for the Confidential Use of the Special Committee on Un-American Activities (1936), 1. While it is quite possible Kellogg was a member of the CP, it is important to emphasize that the Committee on Un-American Activities, and later the House Un-American Activities Committee (HUAC) of the Cold War period, often falsely identified persons as Communists.

${ }^{32}$ Letter from Jessie Duncan and Corrine Williams to Juanita Jackson detailing the anti-lynching program, March 2(?), 1938.
} 
While the Louisville youth were hosting their demonstration, southern senators, illustrative of whom Kellogg spoke, were five weeks into a filibuster, which began on January 6 and ended on February 21, against passage of the most recent anti-lynching legislation, the Wagner-Van Nuys Bill. On the Senate floor, Ellison D. Smith and Allen J. Ellender, Democratic senators from South Carolina and Louisiana, respectively, avowed that were the federal anti-lynching bill to pass, "white civilization [would be] at stake and the South was depending on the North to 'keep this a white man's country."' Unlike Smith and Ellender, however, not all southern senators believed that an anti-lynching bill posed a threat to the existing racial order. Kentucky senators Alben Barkley and Marvel Mills Logan voted for cloture of the Wagner-Van Nuys bill. ${ }^{33}$

The state of Kentucky, like its Deep South counterparts, utilized extra legal tactics to keep African Americans in their place. Between March 1866 and January 1934, an estimated 353 black people were lynched in Kentucky. Yet due to Kentucky’s place in the border region, African Americans had white allies in the government, such as Barkley and Logan, willing to speak out against racialized violence. According to George C. Wright in Racial Violence in Kentucky, 1865-1940: Lynchings, Mob Rule, and Legal Lynchings, 'the first Republican governor, William O. Bradley, played a major role in passing the state's first anti-lynching law; during the 1920s, Governor Edwin Morrow also helped to pass another anti-lynching law. In addition, Governor Augustus E. Wilson

\footnotetext{
${ }^{33}$ On Wagner-Van Nuys filibuster- "New York Senator, Anti-Lynch Leader, Keynoter: Delegates from 27 States At Annual Meet in Columbus," The Louisville Leader (Louisville, KY), July 2, 1938. On Smith and Ellender"Filibuster Continues on Anti-Lynch Bill," The Crisis, February 1938, 56. "2 KY. Senators Vote Yes But Cloture Motion Is Defeated: Both Parties Charged With Betraying Anti-Lynching Bill,” The Louisville Leader (Louisville, KY), Feb. 5, 1938. Cloture would have ended the filibuster, obliging senators to vote on the bill.
} 
called on the state military to stop mob violence by white supremacists in western

Kentucky in the early 1900 s. $^{34}$

The presence and visibility of white allies in Kentucky's struggle to end lynching may have been unique to the South, but interracial alliances in the name of civil rights were prevalent during the 1930s. With the onset of the Great Depression, many African Americans looked to the political Left to contend with their economic plight. Their economic condition, coupled with labor-market discrimination and segregation served as the genesis of "civil rights unionism." 35 The CP, which gained inroads with the African American community because of their ideologies and practices regarding race and race relations, embodied civil rights unionism. ${ }^{36}$ The Party worked in both the North and the South to ensure labor market equality for African Americans and whites. ${ }^{37}$

\footnotetext{
${ }^{34}$ George C. Wright, Racial Violence in Kentucky, 1865-1940: Lynchings, Mob Rule, and 'Legal Lynchings' (Baton Rouge: Louisiana State University Press, 1990), 5.

${ }^{35}$ Hall, "The Long Civil Rights Movement," 1245; Korstad, Civil Rights Unionism, 2003. Unionism entails a collective of workers whose united interest is to secure better or higher wages and better benefits, safer working conditions, and reasonable working hours.
}

${ }^{36}$ According to John Clay Smith in Emancipation: The Making of the Black Lawyer, 1844-1944, the ACP formed to "develop a broad based radical race movement in the United States. Among other things, its goals were to eliminate 'white supremacy ideology 'with its attendant instruments of terror against Negroes,'...[demand] 'complete economic, political, and social equality,' ... [and insists on] 'equal protection on Negroes in all walks of life,' with a guarantee of freedom of speech, press, assembly and petition." John Clay Smith, Emancipation: The Making of the Black Lawyer, 1844-1944 (Philadelphia: The University of Pennsylvania Press, 1993), 106. Unlike the Socialist Party who believed that race should be submerged to issues of class, the ACP believe that white supremacy constituted a part of America's capitalist system, and consequently, that "antiracism should be an explicit part of the anticapitalist struggle. Furthermore, the ACP was the only political party in the United States who, in word and in deed, expressed their opposition to racial inequality. Martha Biondi, To Stand and Fight: The Struggle for Civil Rights in Postwar New York City (Cambridge: Harvard University Press, 2003), 4-6. In 1928, the ACP issued its Black Belt Thesis: Because African Americans in the South were subjected to racial and economic oppression, they constituted a separate nation within the United States. Ibid, 45. During the early 1930s, the CP established Unemployed Councils. The Councils organized the unemployed to secure local resources from relief officials and to seek protection from the state. The Councils were also known for their tenant organizing and reverse eviction campaigns. Karen R. Miller, Managing Inequality: Northern Racial Liberalism in Interwar Detroit (New York: New York University Press, 2015), 181-183; Daniel R. Kerr, Derelict Paradise: Homelessness and Urban Development in Cleveland, Ohio (Amherst: University of Massachusetts Press, 2011), 75-78. While most of their organizing took place in the cites of the urban North, the ACP also made inroads in the rural south, helping to establish labor organizations for sharecroppers, tenant farmers and other agricultural workers. Joyce Moore Turner and W. Burghardt Turner, Caribbean Crusaders and the Harlem Renaissance (Champaign: University of Illinois Press, 2005), 189. In addition, in the North, and also in a few Upper South cites, it assisted blacks in the "Don't Buy Where You Can't Work" campaigns, in which black workers took to the streets to protest discriminatory hiring practices. "Don't Buy Where You Can't Work" Campaigns"' in 
Thus, given white allies in Kentucky's anti-lynching battle and that some African Americans were allied with the CP, the presence of Kellogg, presumed CP member, at the Youth Council's Mass Demonstration is not particularly shocking. What is interesting, however, is his presence at an NAACP sponsored event. The NAACP had a longstanding conflict with the $\mathrm{CP}$, stemming from the CP's allegations that the NAACP failed to defend the Scottsboro Boys in 1931, as well as that the NAACP was a bourgeois organization opposed to the interests of the black working class. ${ }^{38}$ Possibly the NAACP in Louisville, if indeed they were aware that Kellogg possessed ties to the CP, did not share the aversion to the political Left that the national office held. In addition, at the time, a historical moment was underway which saw African Americans and whites with varying political ideologies uniting around various causes. In the post-1935 period, socialist (including the CP) and anti-socialist organizations and individuals united around unionism, anti-fascism and anti-lynching giving birth to the Popular Front. ${ }^{39}$ Thus the presence and provocative speeches of Kellogg and Dunbar (who was a white supporter who followed Kellogg) at the anti-lynching demonstration came as no surprise to those in the audience that evening who were familiar with the existence of white allies in Kentucky's fight against lynching and mob violence, civil rights unionism, and the rise of the Popular Front.

Encyclopedia of U.S. Labor and Working-Class History, Volume I, ed. Eric Arnesen (New York: Routledge, 2007), 380-382.

${ }^{37}$ See Robin D.G. Kelley. Hammer and Hoe: Alabama Communists During the Great Depression (Chapel Hill: The University of North Carolina Press, 1990).

${ }^{38}$ See Gilbert Jonas, Freedom 's Sword: The NAACP and the Struggle Against Racism in America, 1909-1969 (New York: Routledge, 2005), 136-139.

${ }^{39}$ See Michael Denning, The Cultural Front: The Laboring of American Culture in the Twentieth Century (New York: Verso, 1997), especially 4-15. 
After Dunbar took his seat, Miss Ella Moore, accompanied by Mrs. S.L. Taylor, provided the audience with a stirring solo, in preparation for another speaker, Professor Clyde Absalom (C.A.) Liggin. Liggin served as principal of Virginia Avenue, one of the elementary schools for black students in Louisville. ${ }^{40}$ Following Liggin's speech, the highly recognized Glee Club from Louisville Municipal provided the audience with a musical selection. Rev. Ledbetter and Attorney Charles Ewbank Tucker, a distinguished civil rights activist and attorney, who also served as bishop of an AME Zion church and co-editor of the Herald Tribune, followed the Glee Club's performance. Tucker knew all too well the horrors of mob violence, having been assaulted in Elizabethtown, Kentucky in the early 1930s when whites learned he served as attorney for an African American accused of murdering a white farmer. ${ }^{41}$

In the wake of Tucker's somber account, and having been roused by the speeches that exposed the horrors of lynching, the audience voluntarily donated to the cause of ending racialized violence, as Mrs. M.R. Laine and Mrs. Edith Wilson united in song. After all donations were collected, Rev. Johnson closed the program with a benediction. As the congregants made their way out of the sanctuary, the NAACP youth, wearing black armbands to mourn lynching victims, also took the time to sell "Stop Lynching" buttons, to garner support for the anti-lynching legislation and to support the national office in their anti-lynching campaign. ${ }^{42}$

\footnotetext{
40 “Jennie B. Liggin,” accessed May 7, 2015, http://nkaa.uky.edu/record.php?note_id=2480.

41 “Charles Ewbank Tucker,” accessed May 7, 2015, http://nkaa.uky.edu/record.php?note_id=32. Also see John Clay Smith, Emancipation, 330 for Tucker's violent encounter.

${ }^{42}$ Letter from Jessie Duncan and Corrine Williams to Juanita Jackson on anti-lynching program, March(?)1938; Bynum, NAACP Youth, 8 on youth wearing black armbands during anti-lynching demonstrations.
} 
In the weeks following the anti-lynching demonstration, word spread about its success. The Louisville NAACP youth arm had established itself as the voice among black youth in the fight against racism and for racial equality, and other youth were eager to join its ranks. The youth capitalized on the enthusiasm by launching their spring membership campaign on April 19. While busy registering new members, the youth also began making plans to attend the $29^{\text {th }}$ annual NAACP conference, which "promise[d] to be the greatest conference in the history of the Association.” The Youth Council sponsored a rummage sale to fund their trip. ${ }^{43}$

Louisville youth were members of the delegation of 160 youth representing sixteen states that converged on Columbus, Ohio on the evening of Tuesday, June 28 for the NAACP conference celebrating its 29 years in existence. That evening, a number of speakers, including the mayor of Columbus, the vice president of the Columbus NAACP, and NAACP executive secretary Walter White, each welcomed the delegates to the convention. Early the next morning, youth from across the nation broke into group sessions where they discussed residential segregation, voter discrimination, and the desegregation of public accommodations, including restaurants, hotels, movie theatres, public parks and playgrounds. They also debated the best strategies to end these practices. $^{44}$

\footnotetext{
${ }^{43}$ Letter from Jessie Duncan to Juanita Jackson on the spring membership campaign, April 8, 1938, Papers of the NAACP, Part 19: Youth File, Series A: 1919-1939, Reel 4, Group I, Box E-3, Frame 0027, Youth CouncilKentucky, 1937-1939, Black Studies Research Sources. The campaign ended on May 10. Letter from Special Assistant to the Secretary to T.R. Spillman on the $29^{\text {th }}$ annual conference, June 16, 1938, Papers of the NAACP, Part 19: Youth File, Series A: 1919-1939, Reel 4, Group I, Box E-3, Frame 0027, Youth Council—Kentucky, 1937-1939, Black Studies Research Sources. Letter from Jessie Duncan to Juanita Jackson on rummage sale, June 22, 1938, Papers of the NAACP, Part 19: Youth File, Series A: 1919-1939, Reel 4, Group I, Box E-3, Frame 0027, Youth Council—Kentucky, 1937-1939, Black Studies Research Sources.

44،"A Fine Conference Held in Columbus," The Crisis, August 1938, 270. A philosophy professor from the University of Chicago and a state senator from Illinois also welcomed the delegates. "To Push Registration and Aid Fight on Textbooks," The Crisis, August 1938, 273 on the youth group sessions.
} 
These discussions represented the youth's concern with the lack of civil and political rights extended to African Americans, but dialogue on the lack of economic opportunity for African Americans also constituted part of the agenda. In 1932, dissatisfied with the performance of Herbert Hoover, president of the United States when the Depression hit, Americans elected Franklin Roosevelt to the presidency. Immediately after being elected, Roosevelt set out to put America on a path to economic recovery, enacting the New Deal, a legislative program with a three pronged agenda: relief, reform, and recovery. During the "First 100 Days" of Roosevelt's presidency, Congress enacted the programs via legislative acts, and several new agencies were created to implement these programs. ${ }^{45}$

Some of the relief programs established during the First New Deal (1933-1934) were the Agricultural Adjustment Act (AAA), the Civilian Conservation Corps (CCC), the Farm Security Administration (FSA), the National Youth Administration (NYA), and the Works Progress Administration (WPA). ${ }^{46}$ For African Americans, however, many of the programs were implemented discriminatorily, or, if issued in a fair manner, inflicted more harm than good. For example, the AAA, which paid farmers subsidies to reduce crop production caused black sharecroppers and tenants to be evicted from the plantations on which they worked, and the CCC, intended to provide employment to young men, for the most part excluded African American youth. Despite the disparities they faced in New Deal programming, African Americans secured a measure of relief, and

\footnotetext{
${ }^{45}$ See "New Deal," in The Oxford Encyclopedia of Economic History, Volume 1, ed. Joel Mokyr (New York: Oxford, 2003), 71-74. Reform and recovery centered on restoring and stabilizing the economy, and on preventing another Great Depression. The relief platform centered on lifting Americans out of the economic state in which the Great Depression left them by putting them back to work.

${ }^{46}$ Ibid.
} 
demonstrated their appreciation to Roosevelt by gradually shifting their allegiance to the Democratic Party, leaving the Republican Party to which they had been loyal since emancipation. $^{47}$

Cognizant of the depressed economic state and the New Deal's disparate impact upon African Americans, the youth also conversed about the lack of job opportunities for black Americans, discrimination in private jobs, government jobs, and public utilities, and New Deal programs that were implemented discriminatorily, especially in the NYA and the WPA. They deliberated strategies aimed at ending discriminatory practices that included working through the courts, sponsoring boycotts, joining labor organizations, and advocating for passage of labor legislation. The youth had the fortune of having nationally renowned civil rights leaders, including their own Juanita Jackson, lead some of their discussion groups. ${ }^{48}$

On Thursday evening, Dr. Charles Edward Russell captivated the youth with a speech on the misuse of African American history in textbooks. Russell, a founding member of the NAACP and on its Board of Directors, studied textbooks and recorded histories of the Civil War and Reconstruction, and reported how the history of African Americans was "omitted, distorted, or falsified." He encouraged youth to "go back home, secure lists of books used in the schools, examine them and file protests with boards of education, school officials, and others." 49

\footnotetext{
${ }^{47}$ Manfred Berg, “The Ticket to Freedom”: The NAACP and the Struggle for Black Political Integration (Gainesville: University Press of Florida, 2005), 64.

48 "A Fine Conference Held in Columbus," 273. Other speakers included Martin L. Harvey, president of Christian Youth Councils of North America; Rev. James H. Robinson, from the NAACP's National Board of Directors, William T. McKnight, Ohio's assistant attorney general, J.G. St. Clair Drake, and Daisy Lampkin, NAACP field secretary.

${ }^{49}$ Bynum, NAACP Youth, 270.
} 
Inspired by Russell's speech, youth delegates enacted as part of their fall agenda an initiative to demand public schools' removal of racist textbooks and the inclusion of textbooks recording accurate histories of African Americans. The youth also voted to raise $\$ 1,500$ during the next year to support black teachers whose jobs were terminated because of the NAACP's fight for teacher equalization pay. ${ }^{50}$ While the majority of their fall agenda centered on increasing educational equality, the youth also elected to launch voter registration drives, hoping to increase political rights for African Americans. ${ }^{51}$

The successful conference, which ended on Saturday, July 2, had quite an impact upon the members of the Louisville youth delegation who attended. Upon returning, President Duncan expressed that she was "[a]mazed at [the] great work [the] N.A.A.C.P. is doing especially the Youth Branch. It is said that if one can see the great work of a person or organization, he will be inspired... We returned bubbling and with new ideas on what part we, as Negro Youth of America, could play. We have great plans for our council and intend to make it second to none." While the conference marked the end of the Louisville youth's activities for 1938, the Youth Council did receive a new cosponsor, Yolanda Barnett, in December. Barnett was a member of the newly formed Women's Committee, established by the adult branch on December $8,1938 .^{52}$

\footnotetext{
${ }^{50}$ According to Bynum, NAACP Youth, 10, the NAACP's educational agenda had six objectives: "equal lengths of school terms for black and white public schools; equal pay for black and white teachers with the same qualifications; equal school transportation for black and white students; equality in school facilities and equipment; equal per capita expenditures for black and white public education; and equal access to publicly funded graduate and professional schools" (10).

51 “A Fine Conference Held in Columbus," 273.

${ }^{52}$ Letter from Jessie Duncan to Juanita Jackson on conference, July 25, 1938, Papers of the NAACP, Part 19: Youth File, Series A: 1919-1939, Reel 4, Group I, Box E-3, Frame 0027, Youth Council—Kentucky, 1937-1939, Black Studies Research Sources. According to Lee Sartain, Invisible Activists, 53, Women's auxiliaries were not required, but were useful in assisting branches with fundraising and recruiting members; "Women's Committee Formed for Louisville Branch," The Crisis, January 1939, 24; "Women's Committee For Local Association Branch Organized" The Louisville Leader (Louisville, KY), Dec. 17, 1938.
} 
It is interesting, so far as the record suggests, that the Louisville youth did not implement any of the initiatives youth delegates had discussed and voted on during the conference, especially in the realm of educational equality. Had they chosen to execute the proposals, their work could have augmented the work of the adult branch in erasing the color line in education in Louisville. Instead, the youth elected to end their activities for the year.

One reason for this decision was that the youth dedicated the duration of 1938 to setting their agenda for the upcoming year. Shortly after the new year arrived, youth council member Cecil Tarrance traveled to Columbus, Ohio, on Tuesday, January 10 to serve as a delegate to the National Anti-War Youth Congress. ${ }^{53}$ In sending a delegate to the Anti-War Congress, the Louisville youth council joined the interracial youth movement against militarism and fascism that swept the nation during the 1930s. Youth coming of age in the 1930s faced the Great Depression at home and militarism and fascism abroad. Student activism erupted in response, seeking to change America from a "nation sunk in poverty and depression, racked by racial and religious discrimination and seemingly on the 'The Road to War'...to a society governed by the principles of economic and political justice and human equality, living in a peaceful world.. ${ }^{, 54}$

Seeking to transform America, youth engaged in a number of activities, including attending interracial, international youth congresses, such as the meeting held in Columbus. While at the congress, youth, who represented organizations such as the Workers Defense League, the Farmers' Educational and Cooperative Union of America,

\footnotetext{
53 "National Youth Anti-War Groups Meet in Columbus," The Louisville Leader (Louisville, KY), January $14,1939,4$.

${ }^{54}$ Cohen, When the Old Left Was Young, xiii on student activism; John P. Roche, as quoted in Cohen, When the Old Left Was Young, xiv.
} 
and the Religion and Labor Foundation of Hebrew Union College, drafted a War Referendum Amendment, rallied against required R.O.T.C., endorsed the Cooperative Movement, and contested Industrial Mobilization. In 1940, NAACP youth across the nation issued a peace proclamation, becoming the first organization of black youth to publicly oppose the war. Tarrance's participation in the National Anti-War Youth Congress in 1939 thus illustrates that the Louisville Youth Council stood at the vanguard with the NAACP youth movement against warfare. ${ }^{55}$

As spring approached, the Youth Council focused on attracting new youth to their work. With this goal in mind, the council launched a membership drive, which proved to be a success. The spirit of renewal also prompted the youth to elect a new president, Bruce Weaver, who would see the council into a new decade of activism. Not until December, when they elected George Bussey to chair their Christmas Seal Sale, did the Youth Council embark upon any major activities for the year. The sale proved a success, as the group profited ten dollars. ${ }^{56}$ The Christmas Seal Sale marked the culmination of just over two years of organizing in the name of racial equality for the Louisville NAACP Youth Council, who united for the cause of equality in September 1937. Insufficient evidence exists in the archival record, The Louisville Leader and The Crisis to determine whether a catalyst sparked the formation of the youth groups. Consequently, it stands to reason that because the national office organized a youth and

\footnotetext{
${ }^{55}$ See Bynum, NAACP Youth, for attendance at youth congresses throughout the 1930s and 1940s; see pg. 30 for 1940 anti-war declaration. President Roosevelt's Committee on Cooperative Enterprise in Europe defined a cooperative as an enterprise that "belongs to the people who use its services, the control of which rests equally with all its members, and the gains of which are distributed to the members in proportion to the use they make of its services." Samuel A. Rosenberg, "Negro-Managed Cooperatives in Virginia," The Crisis, September 1940, 282. For details of Columbus meeting, see "National Youth Anti-War Groups Meet in Columbus," 4.

56 "Spring Membership Campaign," The Crisis, June 1939, 187. While the numbers are unknown, the Louisville Youth Council reported a successful campaign. "New Youth Leaders," The Crisis, July 1939, 217. "Branches and Youth Councils and their Christmas Seal Chairman," The Crisis, April 1940, 117; "Christmas Seals," The Crisis, February 1940, 61.
} 
college division in 1936, the youth groups in Louisville were formed as part of a general trend of NAACP youth groups erupting across the nation during the time period.

When established, the Louisville NAACP youth built their organization by recruiting members. How did the Youth Council attract youth to join its ranks? The founding twenty-two members of the organization were likely recruited by their teachers given that two of the adults listed on the membership rolls were teachers. Since many of these students were likely classmates, subsequent recruits to the youth council were either fellow peers, or because the youth council was located in Louisville's West End, acquaintances from the community.

In addition, because of its relationship to the parent organization, members of the youth council may have had parents or relatives who were members of the adult branch who encouraged their colleagues to ask youth to join. Therefore, the existing networks that the students possessed served as a basic recruitment tool. While the college chapter was short-lived, students at Louisville Municipal College likely took advantage of their networks as well. Moreover, once the Youth Council established itself as the organ of black youth activism in Louisville, and given the successes of the Youth Council's events, many youth were probably attracted to the work of the Youth Council and decided to join.

While its members served as the lifeline of the Youth Council, the group embarked upon fundraising campaigns to maintain the organization. The Youth Council relied on membership drives as its consistent source of funding. Additionally, the organization used Christmas Seal Sales as an additional source of revenue. Having a fundraising campaign at year's end enabled the Youth Council to start the new year off 
with capital, which proved helpful if yearly organizing and campaigning depleted their account. The Youth Council also utilized some of their programming as opportunities to raise funds, such as the sell of the "Stop Lynching" buttons at the mass demonstration program.

By the end of the 1930s, the Louisville NAACP Youth Council joined the ranks of other NAACP youth groups across the country, which in its embryonic years, placed the crusade against lynching and mob violence high on its political agenda. The antilynching demonstration served as the definitive work of the Louisville NAACP youth in its formative years. As a new decade came into view, the youth arm of the Louisville NAACP would reach new heights in activism. More militant in their stance, the Louisville NAACP youth shifted the focus of their political agenda on seeking redress for political grievances faced by black Louisvillians. While initially off to a slow start, during the interwar period the Louisville NAACP youth, would, as President Duncan proclaimed, become second to none. 


\section{CHAPTER III}

"THE TRUE ASPECT OF A MOVEMENT"57:

LOUISVILLE NAACP YOUTH IN THE INTERWAR YEARS, 1940—1944

Having sponsored an acclaimed anti-lynching demonstration, attended the $29^{\text {th }}$ annual NAACP conference in Columbus Ohio, and protested militarism by sending a delegate to the National Anti-War Youth Congress, Louisville's NAACP Youth Council ended the 1930 s on a successful note. As a new decade arrived, the youth arm of the Louisville NAACP continued to reach new heights in its activism. The youth council organized during 1937 and active until 1939 closed ranks with the short lived college chapter at Louisville Municipal College (LMC) in 1937, and coalesced under the West End Youth Council.

Led by students from Louisville Municipal College and Central High School, Louisville's first high school for black students, this new alliance of college students and high school students fought to secure educational equality and voting rights for African Americans. The East End Youth Council, a newly formed chapter, while less active during the interwar years, also contributed to the cause of educational equality for Black Louisvillians. This chapter details the activism of the Louisville NAACP youth groups in the interwar years, from their start in 1940 as one youth council in Louisville's West End

\footnotetext{
${ }^{57}$ Director of NAACP youth and college division Ruby Hurley in a memorandum to executive secretary Walter White, as quoted in Bynum, NAACP Youth, 42.
} 
protesting closed accommodations, to a multi-body council whose pursuit of racial equality was shaped by war and migration.

By January 1940, Yolanda Barnett, a member of the Women's Committee of the local adult branch, sponsored the Louisville Youth Council, and a new president, Bruce Weaver, led the council. Not until the spring months approached did the Youth Council commence its activities for the year. Hoping to increase its numbers, they sponsored a membership campaign. With new members in its ranks, the Youth Council converged on Chestnut Street, picket signs in hand, and protested outside the Chestnut Street Health Center in response to the lack of recreational facilities available to black people in Louisville. The youth council's demonstration marked the first and final time they articulated their disapproval on the lack of open public accommodations available to African Americans. ${ }^{58}$

At the time of the Health Center picket, a legal battle over the status of the city's segregated municipal parks dominated the work of the adult branch. ${ }^{59}$ It is likely that the youth left the fight for open accommodations to the adults, yet seized the opportunity to augment their work, because as youth, they felt the sting of having race bar them from enjoying a day at the park or reading a book in a library.

While the youth council staged only one major activity in 1940, 1941 marked a turning point for the council. 1941 also proved to be a seminal moment for African Americans for two reasons: the second wave of the Great Migration and the March on Washington Movement (MOWM). In September 1939, militarism and fascism could no

\footnotetext{
${ }^{58}$ N.A.A.C.P. Louisville Branch, Annual Meeting and Election of Officers, Sunday, January 21, 1940, Papers of the NAACP, Part 26: Selected Branch Files, 1940 - 1955, Series A: The South, Reel 11, Group II, Box C66, Frame 0399, Louisville, Kentucky, 1940-1944, Black Studies Research Sources; "Spring Campaigns," The Crisis, April 1940, 120. McElhone, Civil Rights Activities, 61 on Chestnut Street pickets.

${ }^{59}$ McElhone, Civil Rights Activities, 60-61.
} 
longer be contained, and the world was at war for the second time. As war raged abroad, a defense industry opened in the United States, stimulating the end of the Great Depression, the greatest economic downturn that the Western world had ever experienced.

Much like World War I, the second world war prompted the mass movements of millions of African Americans from small rural towns of the South to urbanized, metropolitan cites, in search of an economic future that did not involve toiling away as sharecroppers. As African Americans arrived and settled in the metropolises, however, Jim Crow followed them. Those jobs that propelled them to leave home were unavailable. A number of employers outright refused to hire any black workers on the basis of their race; those that did hire relegated African Americans to domestic and service positions. ${ }^{60}$

In response to the labor-market discrimination and segregation, Asa Phillip Randolph, union leader of the Brotherhood of Sleeping Car Porters, the sole black led labor union in the American Federation of Labor (AFL), threatened a march on the nation's capital in the summer of 1941 to protest discriminatory hiring practices in America's defense industry. The movement galvanized African Americans who, in response, launched smaller committees throughout the country to support the effort, propelling the proposed march into a Movement. ${ }^{61}$

The NAACP, which had only marginally recognized the needs of black workers, and which was generally opposed to militant protest politics, supported Randolph's

\footnotetext{
${ }^{60}$ For the seminal work on the Great Migration, see Isabel Wilkerson, The Warmth of Other Suns: The Epic Story of America's Great Migration (New York: Vintage Books, 2010).

${ }^{61}$ See David Lucander, Winning the War for Democracy: The March on Washington Movement, 1941-1946 (Champaign: University of Illinois Press, 2014).
} 
effort, and its youth arm endorsed the movement as well. Now under the tutelage of Madison S. Jones, NAACP youth groups advocated for eliminating the discrimination of African Americans in labor unions and employment and also initiated American Negro Youth Week (ANYW). ${ }^{62}$

During ANYW, the national NAACP celebrated the accomplishments of African American youth and implemented programs that were directed towards their goals and needs. In addition to implementing a large project, the NAACP youth held social events such as Social Activity and Parade Day to attract more members. NAACP youth groups bolstered the March on Washington Movement via ANYW by engaging in a fact-finding mission on the number of African Americans employed in the defense industry. ${ }^{63}$

The same dynamism that touched other major cities touched Louisville as well. While the Great Migration served as an exodus for millions of African Americans from the South to the Northeast, Midwest, and West, millions of African Americans chose to remain in the South. In Way Up North in Louisville: African American Migration in the Urban South, 1930 - 1970, historian Luther Adams writes, "At a time when roughly half the black population left the South seeking greater opportunity and freedom in the North and West, that same desire was often a catalyst for some blacks to remain in the South." ${ }^{64}$ Many black people journeying from small rural towns to large urban cities thus made Louisville their home. Because its economy mirrored that of cities of the Northeast and Midwest, African Americans voyaged to Louisville to obtain jobs in the manufacturing

\footnotetext{
${ }^{62}$ Bynum, NAACP Youth, 33.

${ }^{63}$ Ibid.

${ }^{64}$ Luther Adams, Way Up North in Louisville: African American Migration in the Urban South, 1930-1970 (Chapel Hill: The University of North Carolina Press, 2010), 1.
} 
and commercial industries, but faced labor-market discrimination, for which they sought redress. $^{65}$

While nationally the momentum for Randolph's MOWM increased, in Louisville, the adult branch responded tepidly to the issues of discrimination faced by black workers in the city. In 1941, the local Association presented plans to launch demonstrations outside of construction sites and defense plants that refused to hire African Americans. W. Augustus Jones, president of the senior branch, argued that were the pickets to take place, the efforts would not bear much fruit since Louisville lacked an adequate number of skilled black workers to fill open positions. As a consequence, the local Association focused their efforts on teaching young black men skilled trades. ${ }^{66}$ While their level of involvement with the adult's work in extending opportunity for Louisville's black workers is inconclusive, Louisville's Youth Council offered financial support to the national MOWM by selling 100 National Negro Youth Week tags in celebration of ANYW. ${ }^{67}$

Additionally, the youth council capitalized on the vitality of the moment, sponsoring a spring membership campaign, and re-electing officers. They successfully recruited 35 new members, some of whom indeed may have been the progeny of new migrants to the city. ${ }^{68}$ As African Americans migrated from rural areas to urban areas in the South, they were afforded rights of which they were formerly stripped; one such

\footnotetext{
${ }^{65}$ Ibid, 29, "The numbers of migrant families...indicates that Louisville was swelled not only by the large numbers of women and men who came seeking employment, but also by the families who accompanied them. These figures suggest as well the large numbers of African Americans who were lured to Louisville during the war by the hint of opportunity."

${ }^{66}$ McElhone, Civil Rights Activities, 123-124.

67 “Youth Council News_Activities: Louisville, Ky.," The Crisis, July 1941, 232.

${ }^{68}$ Ibid.
} 
opportunity was the right to vote. With a political economy mirroring regions outside of the South, Louisville offered to migrants access to the ballot. Armed with this powerful tool, African Americans finally possessed a weapon to resist the racial status quo. As Adams writes, "Migrants went to Louisville with the resolve to improve the social, economic, and racial climate for African Americans in the South. ${ }^{69}$ Empowered by the new possibilities that transitioning from the Deep South offered, the children of these migrants also embraced that same sense of empowerment, prompting them to join the ranks of the Louisville NAACP Youth Council.

One week before 100,000 black people were set to March on Washington, President Roosevelt signed Executive Order \#8802, which banned discrimination in the defense industry, and which established the Fair Employment Practices Committee (FEPC), which would enforce the Order. ${ }^{70}$ With the United States' entrance into World War II in December 1941, a MOWM that continued to thrive, and the dispersal of millions of African Americans throughout the nation's metropolises, African Americans entered 1942 with a spirit of hope and renewal, the essence of which could be felt in Louisville.

On March 3, 1942, Bessie Etherly, then secretary of the Louisville adult branch, drafted a letter to Lucille Black, executive assistant of the national department of branches, indicating that a "young lady [was] recently elected as sponsor [of the] East

\footnotetext{
${ }^{69}$ For information on access to the ballot in Louisville, see Adams, Way Up North in Louisville, 38; for more on why African Americans chose to remain in the South, Ibid, 1.

70 "March on Washington (1941)" in African Americans at War: An Encyclopedia, Volume 1, ed. Jonathan Sutherland (Santa Barbara: ABC-CLIO, Inc., 2004 ), 260-261.
} 
End Youth Council (EEYC) ${ }^{71}$ With the formation of the EEYC, Louisville now had two NAACP youth groups ready to agitate for social change. What, then, prompted the formation of a second youth council in the city?

Gloster B. Current, then executive director of the Detroit branch and later national director of branches, explained the existence of multiple youth councils in an article published in the May 1939 issue of The Crisis. ${ }^{72}$ Current contended that in Detroit, which had six NAACP youth groups, ${ }^{73}$ multiple youth councils existed for three reasons: first, the dispersal of the black population throughout a metropolitan city makes it "impossible for the influence of a single council to be felt throughout the city;" secondly, that the distance between communities makes it difficult for youth to transport themselves from one side of town to another; and lastly, intra-racial conflict hinders the development of a single city-wide youth council. ${ }^{74}$

In Louisville, when the youth arm of the Louisville NAACP formed in 1937, the founding members resided in the city's West End, where the majority of African Americans lived between 1900 and $1946 .^{75}$ The short-lived college chapter, housed at Louisville Municipal College (LMC) from the fall of 1937 until the spring of 1938, was also located in the West End. The archival record provides no indication on the exact

\footnotetext{
${ }^{71}$ Letter from Bessie S. Etherly to Lucille Black, March 3, 1942, Papers of the NAACP, Part 26: Selected Branch Files, 1940 - 1955, Series A: The South, Reel 11, Group II, Box C - 66, Frame 0399, Louisville, Kentucky, 1940-1944, Black Studies Research Sources.

${ }^{72}$ For background on Current, see Sullivan, Lift Every Voice, 49, and Bynum, NAACP Youth, 63.

${ }^{73}$ The black population was dispersed throughout the North End, North Detroit, East Side, West Side, Delray, Highland Park, Hamtramck, and Eight Mile Road until two adults organized three councils in the city's West Side, North End, and Eight Mile Road sections in 1936. By 1939, Detroit had six youth councils: North End, West Side, Birdhurst, East Side, North Detroit, and Highland Park. Gloster B. Current, "Detroit's Multiple Youth Councils," The Crisis, May 1939, 146.

74 Ibid.

${ }^{75}$ McElhone, Civil Rights Activities, 17.
} 
time of its formation, but between spring 1941 and early 1942, the college chapter resurged and along with the existing youth council, coalesced under a West End Youth Council (WEYC).

The WEYC may not have reached black youth in other parts of the city, thus spurring the formation of a youth council in the East End, another area in Louisville with a significant black population. However, historical circumstances cannot be ignored. It is highly probable that as the Great Migration brought African Americans to Louisville, they settled into its East End. ${ }^{76}$ Cognizant of the work of the NAACP and its youth groups, and armed with the desire for change, these youth may have helped to establish an NAACP youth council in the city's East End.

Mrs. Nan Rogers sponsored the East End Youth Council (EEYC), and Mr. Ainslie Kenzer and Mrs. Minnie Larkins served as president and secretary, respectively. By October 1943, the EEYC established itself in the community, having engaged in "activities over a period which included forums, a symposium of ministers of the community, a rummage sale, and a birthday dance." ${ }^{, 77}$ On February 6, 1944, the EEYC elected officers. Because Kenzer and Larkins presently led the council, it is likely that the vice president (Miss Maude Ferguson), assistant secretary (Mary Lou Eaves (sp.?), and treasurer (Rev. Oliver (sp.?) were also elected on February $6 .^{78}$

\footnotetext{
${ }^{76}$ For example, historian Luther Adams writes that "Smoketown, bounded by Broadway and Kentucky, and Shelby to First Street and Smoketown, was of the few large Black enclaves located east of the central business district, outside the West End. Luther Adams, "Way Up North in Louisville: African-American Migration in Louisville, Kentucky, 1930-1970” (PhD diss., University of Pennsylvania, 2002), 99-100.

77 "Youth Council Activities: Louisville, Ky. (East End)," The Crisis, October 1943, 311.

${ }^{78}$ Letter from Ainslie Kenzer, Minnie Larkins, and Nan Rogers to Ruby Hurley, April 19, 1944, Papers of the NAACP, Part 26: Selected Branch Files, 1940 - 1955, Series A: The South, Reel 11, Group II, Box C-66, Frame 0399, Louisville, Kentucky, 1940-1944, Black Studies Research Sources.
} 
With an expanded leadership team, the EEYC embarked upon enacting their political agenda, the first of which served as a collaborative effort with the WEYC. The executive committee of the EEYC met with the WEYC's executive board to plan a threeday conference to be held at the end of February. The youth secured the three locations at which the conference would be hosted: the Brock Building, Louisville's preeminent social club for African Americans located on 639 South Ninth Street; the Phillis Wheatley YWCA, which African Americans patronized; and the Recreation Center at Beecher Terrace, one of the three (College Court and Sheppard Square) public housing projects constructed for African Americans in Louisville between 1937 and $1940 .{ }^{79}$ The youth groups also secured the cooperation of several guests to the conference, including visitors from the University of Louisville, and Lyman Johnson, an esteemed educator and civil rights activist in the city, who also served as president of the local NAACP at the time.

On Friday, February 25, dressed in gowns and tuxedos, youth representing the EEYC, the WEYC, and numerous friends of both councils, converged on 639 South Ninth Street. That night the youth councils, alongside their friends, enjoyed an evening of dance. The next day, members of the East End and West End youth councils traveled to the YWCA, joined by visitors from the University of Louisville, and discussed strategies for fostering "Better Race Relations" in the city. On the last day of the conference,

\footnotetext{
${ }^{79}$ On the Brock Building, see Bruce M. Tyler, African-American Life in Louisville (Charleston: Arcadia Publishing, 1998), 119; on public housing projects, see Adams, Way Up North in Louisville, 45.
} 
Sunday, February 27, the EEYC and WEYC invited the community to a mass meeting held at Beecher Terrace's Recreation Center, featuring a principal address by Johnson. ${ }^{80}$

The NAACP did not document the proceedings of the interracial symposium, nor the community mass meeting, but key facts suggest the three-day conference centered on the state of education in Louisville. At the time of the conference, the NAACP adult branch was in the middle of a complex legal battle to integrate the University of Kentucky (UK) that began in 1941 when Charles Lamont Eubanks applied to the University of Kentucky's engineering school. School officials denied Eubanks admission, citing Kentucky's Day Law, an act of legislation created in 1904 that forced white and black children in Kentucky into separate schools at all levels. ${ }^{81}$

Although not an attorney, as president of the local adult branch and a highly valued educator, Johnson played (and would play) a significant role in efforts to desegregate the state's flagship university. As a consequence, it is likely that his speech at the mass meeting centered on addressing inequities in Kentucky's educational system. Furthermore, because Minnie Harrison (president) and Ollie Chatmond (sp.?) (vice president), both students from Louisville Municipal College, the city's black division of the University of Louisville (UL), led the WEYC, it is possible that the officers spearheaded the interracial symposium, which, given the present fight to desegregate UK, may have discussed efforts to integrate the UL. Moreover, only a month earlier, the WEYC, acting as an independent entity, sponsored a remarkably similar program to the interracial symposium, an "Inter-Racial program at the University [of Louisville], with

\footnotetext{
${ }^{80}$ The Louisville Youth Council of the N.A.A.C.P: Activities of the West End Branch (June 1943_-June 1944). Papers of the NAACP, Part 26: Selected Branch Files, 1940-1955, Series A: The South, Reel 11, Group II, Box C-66, Frame 0399, Louisville, Kentucky, 1940-1944, Black Studies Research Sources.

${ }^{81}$ On struggle to integrate UK, see McElhone, Civil Rights Activities, 97-100; "Day Law" in The Kentucky Encyclopedia, ed. John E. Kleber (Lexington: The University Press of Kentucky, 1992), 258.
} 
members of faculty and student body participating; [concerning] "discrimination and segregation as practiced in our southern schools." 82 Taken as a collective, these factors substantiate the claim that the three-day youth conference centered on ending educational inequality in Louisville.

Following the three-day conference, the EEYC launched a membership campaign, and with its new members, celebrated National Negro Youth Week. ${ }^{83}$ A lack of evidence in the archival record does not make it possible to conclude whether the EEYC implemented any additional activities for the duration of the interwar years. While the exact times of their events are unknown, the WEYC, however, continued working to secure racial equality, especially in the area of educational equity. One of their efforts entailed launching a letter-writing campaign to the Kentucky House of Representatives petitioning for immediate repeal of the Day Law. ${ }^{84}$

The WEYC also attended a session at the Kentucky Negro Educational Association (KNEA). Formed in 1913, the KNEA was the 'representative body' of Kentucky's black educators that lobbied for educational equality. The group had a strong presence in Louisville as they hosted their annual conferences in the city. The KNEA sponsored essay writing and spelling contests for students every year, and exhibited industrial and fine arts works created by students. Its members worked for teacher equalization pay and the end to educational inequities in black schools, fought to

\footnotetext{
${ }^{82}$ Letter from Lavinia N. Sedwick to Ruby Hurley, January 8, 1944, Papers of the NAACP, Part 26: Selected Branch Files, 1940 - 1955, Series A: The South, Reel 11, Group II, Box C—66, Frame 0399, Louisville, Kentucky, 1940-1944, Black Studies Research Sources.

${ }^{83}$ Letter from Ainslie Kenzer, Minnie Larkins, and Nan Rogers to Ruby Hurley on work of EEYC, April 19, 1944, Papers of the NAACP, Part 26: Selected Branch Files, 1940-1955, Series A: The South, Reel 11, Group II, Box C-66, Frame 0399, Louisville, Kentucky, 1940-1944, Black Studies Research Sources.

${ }^{84}$ The Louisville Youth Council of the N.A.A.C.P.: Activities of the West End Branch (June 1943-June 1944).
} 
integrate graduate schools at the University of Kentucky, and like the WEYC, worked to repeal the Day Law. ${ }^{85}$

The WEYC's activism in working to make the Day Law ineffective is significant given that for African American students, the education system in Louisville, even under Jim Crow, was superior. Both Central High School and Louisville Municipal College were accredited and possessed highly recognized teachers and curriculum. The WEYC had access to an education many other African Americans, especially in the South, could only have dreamed of. ${ }^{86}$ Yet, its members saw the insolvency in maintaining a system which remained segregated and fundamentally unequal, and fought to make it equal. Though many of the WEYC's efforts centered on securing educational equality, as war raged abroad, the council also saw the need for and contributed to war efforts by working to secure political rights for African Americans. Throughout the war years, political rights, especially the right to vote, were of prime importance to African Americans who, although in segregated units, served with much honor and distinction in America's armed forces. Their hope, captured in the Double V Campaign, was that African Americans' valiant fight for America would help them to secure "Victory at Home and Abroad" against racism and fascism. ${ }^{87}$

The same spirit that captured African Americans nationally trickled down to Louisville and infused the WEYC. The group, whose junior members had initially

\footnotetext{
85 "Kentucky Negro Educational Association,” accessed April 22, 2015, http://nkaa.uky.edu/record.php?note_id=410; "Kentucky Negro Educational Association," in The Kentucky Encyclopedia, ed. John Kleber (Lexington: The University Press of Kentucky, 1992), 507.

${ }^{86}$ Adams, Way Up North in Louisville, 114-116, writes that some African Americans migrated to Louisville because of the educational opportunities.

${ }^{87}$ The Pittsburgh Courier, a black newspaper, launched the Double V campaign. See "Double V Campaign" in Jim Crow: A Historical Encyclopedia of the American Mosaic, ed. Nikki L.M. Brown and Barry M. Stentiford (Santa Barbara: ABC-CLIO, Inc., 2014), 139-142.
} 
opposed the war effort when they sent a delegate to the National Anti-War Youth Congress in early 1939, now supported the fight for democracy, notably by offering aid to African American soldiers in Louisville who patronized the United Service Organizations (U.S.O.). Established in February 1941 by President Franklin Roosevelt, a federation of organizations comprised the U.S.O., and provided recreational activities and entertainment for U.S. troops. ${ }^{88}$ In Louisville, the U.S.O. opened on March 7, 1941 to serve troops from neighboring Bowman Field and Fort Knox, but due to the color line, a separate U.S.O. opened for African American troops on Chestnut Street. ${ }^{89}$ The WEYC collected books and donated them to the U.S.O. for the soldiers' use, celebrated Black History Week with the soldiers, and donated funds to the organization. The WEYC soon developed a bond with the black soldiers, with whom they held speaking engagements, including one from Cornell Ridly (sp.?), "a former member now in service." perhaps this personal relationship they shared that propelled them to advocate on behalf of soldiers' right to vote.

The Green-Lucas Bill, or Soldier Vote Bill, went into Congress in December 1943. The soldier vote was a form of absentee voting whereby soldiers would receive blank ballots prior to the election and cast their vote for federal elections. Soldiers were eligible for the vote granted they met the requirements to vote in their home state. A War Ballot Commission, which included four members of both political parties, would

\footnotetext{
${ }^{88}$ The International Committee of the YMCA, the National Board of the YMCA, the National Catholic Community Service, the Salvation Army, the National Jewish Welfare Boards (JWB), and the National Travelers Aid Association (TAA). "History," United Service Organizations, accessed April 22, 2015, http://www.uso.org/history.aspx

${ }^{89}$ Bruce Michael Tyler, Images of America: Louisville in World War II (Charleston, Arcadia Publishing, 2005), 99, 107.

90 "Youth Council Activities: Louisville, Ky. (West End)," The Crisis, October 1943, 311. The Louisville Youth Council of the N.A.A.C.P.: Activities of the West End Branch (June 1943-June 1944).
} 
oversee the process. Southern congressmen, however, feared that if the Green-Lucas Bill passed, black soldiers could be exempted from paying the poll tax, one of the several measures that prevented African Americans (and poor whites) from voting, thus effectively laying a precedent for reversing the massive disenfranchisement of black people in the South. Southern congressmen were not to be dissuaded, and crafted a compromise bill which would yield to states the power to distribute the ballots, thereby giving southerners free reign in choosing which soldiers were eligible to vote in the federal elections. This, in effect, would provide them the means to prevent black soldiers from voting. ${ }^{91}$

The WEYC recognized the irrationality in depriving African Americans of their political rights when they were fighting to protect democracy, and thus sponsored a letterwriting campaign encouraging congressmen to pass the Green-Lucas Bill. To

Representative Eugene Worley, Sponsor Sedwick and President Minnie Harrison wrote:

Dear Sir:

The "West End Youth Council" of the N.A.A.C.P. has been interested in the "Soldier Vote Bill," and realizing your viewpoint, we are asking that you work for the passage of the original Green-Lucas Bill and make no compromise.

The compromise bill still gives the State the right to say whether soldiers' ballot will be received or counted, and as a result of this; the soldiers, particularly the Negro and whites from poll tax states, find themselves just about where they were at first. There must be no compromise in the Federal responsibility to see that the soldiers vote is cast and counted. ${ }^{92}$

The WEYC also penned a letter to an unidentified congressman:

\footnotetext{
${ }^{91}$ Kimberley Johnson, Reforming Jim Crow: Southern Politics and State in the Age Before Brown (New York: Oxford University Press, 2010), 100-101.

${ }^{92}$ Letter from Minnie Harrison and Lavinia N. Sedwick to Representative Eugene Worley, January 18, 1944. Papers of the NAACP, Part 26: Selected Branch Files, 1940-1955, Series A: The South, Reel 11, Group II, Box C66, Frame 0399, Louisville, Kentucky, 1940-1944, Black Studies Research Sources.
} 


\section{Dear Sir:}

The "West End Youth Council" of the N.A.A.C.P. is asking you to support the principle of the original Green-Lucas-Worley Bill, making it mandatory upon the states to accept properly certified solider ballots.

The compromise bill does not give the Federal Commission the power to pass upon the validity of ballot, but does pass this power to the states. The soldiers, particularly the Negro and white from Poll-tax states, find themselves just about where they were at first. The State still has the right to say whether soldiers' ballot will be received or counted. There must be no compromise in the Federal responsibility to see that the soldiers vote is cast and counted. ${ }^{93}$

Cognizant of the fact that unless Congress also passed an anti-poll tax bill, Southern congressmen would still possess a legal means to prevent African Americans from voting, the WEYC sent telegrams to Senators pressing for passage of an anti-poll tax bill.

To US Senators Alben W. Barkley and Albert Chandler of Kentucky, Harrison and Sedwick wrote:

\section{Dear Sir:}

The "West End Youth Council" of the N.A.A.C.P. is depending upon you to vote for cloture on the Anti-Poll Tax Bill, H.R.7. We appreciate to an extent what you did before, but believe sincerely that failure to vote for cloture on this bill, is failure to vote for victory.

For the right to vote is a basic right of a democracy. Any Senator who filibusters to prevent any citizen from voting now, hampers the war effort and delays victory.

We have confidence in you, so are waiting and hoping. ${ }^{94}$

\footnotetext{
${ }^{93}$ Letter from Minnie Harrison and Lavinia N. Sedwick to unknown congressmen, date unknown. Papers of the NAACP, Part 26: Selected Branch Files, 1940-1955, Series A: The South, Reel 11, Group II, Box C-66, Frame 0399, Louisville, Kentucky, 1940-1944, Black Studies Research Sources.

${ }^{94}$ Letters from Minne Harrison and Lavinia N. Sedwick to Senators Alben W. Barkley and Albert Chandler, January (18?), 1944. Papers of the NAACP, Part 26: Selected Branch Files, 1940-1955, Series A: The South, Reel 11, Group II, Box C—66, Frame 0399, Louisville, Kentucky, 1940-1944, Black Studies Research Sources.
} 
Not until 21 years later when the $24^{\text {th }}$ Amendment passed did the poll tax cease to exist. Southerners blocked passage of the Green-Lucas Bill, enacting their 'State Control' bill that allowed the states to chose what soldiers were eligible to vote for federal elections, giving southerners the power to keep black soldiers from voting. ${ }^{95}$

Yet given the WEYC's place in the border region, its letter-writing campaigns were significant. Whereas in the Deep South, where black people were massively disenfranchised and often slain for simply attempting to register to vote, in border cities, as in the northeast and Midwest, African Americans were never systematically denied the right to vote. Voter registration drives still existed in the border, ${ }^{96}$ but "having grown up in a society where blacks voted, [whites] did not share the Deep South's aversion to the concept of blacks voting...Their sense of what it was to be white or black was not tied to white enfranchisement and black disenfranchisement." ${ }^{, 97}$ Thus the work of the WEYC in advancing political rights for African Americans suggests they recognized that their place in the Border South afforded them rights that African Americans farther South did not possess.

For their efforts, the WEYC received much acclaim from the national office. In response to their campaign, Ruby Hurley, current director of the national youth and college division, wrote: "Your report on the activities of the youth council caused quite a bit of furor in this office. We were so pleased with the letters that went to the

\footnotetext{
${ }^{95}$ Johnson, Reforming Jim Crow, 101.

${ }^{96}$ As in the case of Cambridge, Maryland's Project Eastern Shore. Levy, Civil War on Race Street, 57-59.

${ }^{97}$ Ibid, 58.
} 
Congressmen on the Soldiers' Vote Bill that copies were sent to our Washington Bureau and copies were used in the NAACP Youth New Letter." ${ }^{\text {98 }}$

The WEYC did not limit their letters to the government's legislative branches. Foreshadowing the momentous event that would come over two decades later, they sent a telegram to the nation's capital, asking President Roosevelt to place a "Negro on the Supreme Court." ${ }^{, 99}$ The WEYC's letters even touched California. Contributing to the NAACP's cultural campaign for racial equality, a part of which entailed seeking to end stereotypical portrayals of African Americans in television and movies, ${ }^{100}$ the WEYC penned a "Letter to Hollywood," signed by an unprecedented 600 Louisvillians, in hopes that "Negroes play better roles in pictures."

As a civically engaged body, the WEYC volunteered with the O.P.A. (Office of Public Advocacy) and met with an O.P.A. representative to discuss economic inequality in Louisville. They also lent their time to support the adult branch, for which they reviewed bulletins, and assisted in their Emancipation Program and membership drives. ${ }^{102}$ While the WEYC concentrated most of their efforts on implementing their political agenda, they also remembered to have fun.

\footnotetext{
${ }^{98}$ Letter from Ruby Hurley to Lavinia Sedwick, January 27, 1944, Papers of the NAACP, Part 26: Selected Branch Files, 1940 - 1955, Series A: The South, Reel 11, Group II, Box C-66, Frame 0399, Louisville, Kentucky, 1940-1944, Black Studies Research Sources.

${ }^{99}$ The Louisville Youth Council of the N.A.A.C.P.: Activities of the West End Branch (June 1943-June 1944).

${ }^{100}$ Jenny Woodley, Art for Equality: The NAACP's Cultural Campaign for Civil Rights (Lexington: The University Press of Kentucky, 2014), 10.

101 The Louisville Youth Council of the N.A.A.C.P.: Activities of the West End Branch (June 1943-June 1944).

102 Ibid.
} 
To foster a closer relationship amongst the council given its composition of both high school and college students, the WEYC arranged a number of social gatherings. They celebrated Youth Week at LMC's campus with an assembly program, held a skating party, picnicked at Chickasaw Park, Louisville's sole municipal park open to black people at the time, and documented what would become lifelong memories by crafting a scrap book. ${ }^{103}$

The WEYC also embarked upon a membership drive. Attracting youth from both the high school and college level, the WEYC successfully recruited nearly 50 members. They displayed the fruits of this labor when they sold 2500 Christmas Seals during the holiday season! With profits in hand from the Seal Sale, the WEYC purchased gifts to lift the Christmas spirits of residents at the Home of the Aged. ${ }^{104}$

"My feeling is that this is the beginning of our youth work taking on the true aspect of a Movement," wrote Ruby Hurley, who would serve as director of the national youth and college division from 1943 until 1951, to the Association's executive secretary Walter White in $1944 .{ }^{105}$ Hurley's sentiments proved to be true, especially in Louisville. During the interwar years, the youth arm of the Louisville NAACP reached a level of success that would be unmatched in its years of existence. The youth arm's activism during this period was bolstered by the establishment of two councils which played a seminal role in black Louisvillians' struggle for racial equality.

While the EEYC must be praised for its contributions, the WEYC, likely because its members were more experienced in organizing, remained more active during the
103 Ibid.
104 Ibid.
${ }^{105}$ Hurley in a memorandum to Walter White, as quoted in Bynum, NAACP Youth, 42. 
interwar years than did the EEYC. During this time, the WEYC centered much of its work on securing educational equality in Louisville. Because the pursuit of educational equality was a platform of the national youth division, and thus implemented in some fashion by NAACP youth groups across America, the distinctiveness of the WEYC's work for educational equality lay in the fact that the youth worked across racial lines in their efforts, making their work distinctly different from cities located farther south. In the postwar years, the youth arm of the Louisville NAACP would continue to play a seminal role in the fight for educational equality. 


\section{CHAPTER IV \\ “RED SCARED”: LOUISVILLE NAACP YOUTH, 1945-1955}

The interwar years represented a seminal moment for the youth arm of the NAACP in Louisville. Influenced by the war abroad and migration at home, two councils, representing the city's West End and East End, emerged and embarked upon securing educational and political rights for African Americans. While archival evidence indicates that in the immediate post-war period the East End Youth Council experienced a drop in activity, the West End Youth Council, on the other hand, continued to pursue racial equality. Youth political activity remained high when in 1948, a separate interracial college chapter, housed at Louisville Municipal College, emerged. The promise of this interracial college chapter was soon overshadowed by a political fury that swept the nation during the late 1940s and early 1950s. This chapter documents the activities of the Louisville NAACP youth groups from the immediate post-war period until the rise and decline of the Red Scare.

In 1945, the West End Youth Council (WEYC) took advantage of the joy that filled Americans as democracy prevailed over militarism. ${ }^{106}$ As the New Year began,

${ }^{106}$ As of June 22, 1945, an EEYC still existed, but it did not have a sponsor. Papers of the NAACP, Part 26: Selected Branch Files, 1940-1955, Series A: The South, Reel 11, Group II, Box C-66, Frame 0586, Louisville, Kentucky, 1945-1949, Black Studies Research Sources. 
they were " $100 \%$ for the success of [the] movement" to contribute to the national office's Willkie Building Fund. ${ }^{107}$ The NAACP was in the process of renaming their New York headquarters in memoriam of Wendell Willkie, who passed away in October 1944. Willkie, a Republican presidential candidate in 1940, supported efforts to achieve racial equality. ${ }^{108}$ The financial contributions of the WEYC likely came from the tag sale they sponsored, chaired by Miss Carolyn Roberson, during the spring season. The council also utilized the season to sponsor a successful membership drive, having raised $\$ 15.50$. In terms of its political agenda, the WEYC worked on preventing juvenile delinquency. During the holiday season, the council sponsored its annual Christmas Seal sale, profiting $\$ 50.00$. Additionally, five days before Christmas, the WEYC gathered at the Phillis Wheatley YWCA with family and friends to celebrate the joy of the season at a large Christmas Party. ${ }^{109}$

Despite a lull in activity between 1946 and 1947, there was a resurgence of activity in the youth arm in 1948 when Elvira Williams, a member of the adult branch, wrote a letter to Lucille Black, executive assistant at the national department of branches, inquiring about restarting a junior council, which included youth aged $12-15$, in

\footnotetext{
${ }^{107}$ Letter from Lavinia N. Sedwick to Ruby Hurley, January (?) 1945. Papers of the NAACP, Part 26: Selected Branch Files, 1940-1955, Series A: The South, Reel 11, Group II, Box C-66, Frame 0586, Louisville, Kentucky, 1945-1949, Black Studies Research Sources.

108 "Youth Council News: Willkie Building Fund," The Crisis, April 1945, 115.

${ }^{109}$ Letter from Carolyn M. Robeson to Ruby Hurley, May 18, 1945. Papers of the NAACP, Part 26: Selected Branch Files, 1940 - 1955, Series A: The South, Reel 11, Group II, Box C-66, Frame 0586, Louisville, Kentucky, 1945-1949, Black Studies Research Sources. On preventing juvenile delinquency, see Photo, West End Youth Council Group of the NAACP, Date Unknown, Papers of the NAACP, Part 26: Selected Branch Files, 1940-1955, Series A: The South, Reel 11, Group II, Box C-66, Frame 0586, Louisville, Kentucky, 1945-1949, Black Studies Research Sources. Letter from Lavinia N. Sedwick to Ruby Hurley on holiday events, Date Unknown, Papers of the NAACP, Part 26: Selected Branch Files, 1940-1955, Series A: The South, Reel 11, Group II, Box C-66, Frame 0586, Louisville, Kentucky, 1945-1949, Black Studies Research Sources.
} 
Louisville. ${ }^{110}$ In April, James Crumlin, the most recently elected president of the adult branch, informed Gloster Current, national director of branches, that the adult branch organized a college chapter at Louisville Municipal College (LMC). Crumlin wrote, "We are endeavoring to have it composed of members of the University of Louisville (white) as well as Municipal students. The officers have been elected; Campaign Chairman has been appointed; they are doing fairly well." ${ }^{111}$

What accounted for the interest in organizing a junior youth council, the emergence of an independent college chapter, and what became of the East End and West End Youth Councils by 1948? To begin with, as 1945 began there still existed an EEYC, but evidence is insufficient to conclude whether they remained active. Next, the WEYC had been an incredibly successful group from the time of its inception in the early 1940s up until 1945. Because there is no indication in the historical account on the activities of the youth arm between 1946 and 1947, because college students from LMC served as both leaders and members in the WEYC during its active years, and given that an independent college chapter housed at LMC formed in 1948, it is likely that the WEYC ceased to exist after 1945.

Furthermore, while evidence is inconclusive to determine whether the adult branch followed through with their interest in reorganizing a junior youth council, it is also likely that with the (possible) dissolution of the WEYC, the adult branch wanted to implement a junior youth council to host young Louisvillians aged 12-15, while the

\footnotetext{
${ }^{110}$ Letter from Elvira Williams to Lucille Black, January 26, 1948, Papers of the NAACP, Part 26: Selected Branch Files, 1940 - 1955, Series A: The South, Reel 11, Group II, Box C-66, Frame 0586, Louisville, Kentucky, 1945-1949, Black Studies Research Sources.

${ }^{111}$ Letter from James Crumlin to Gloster B. Current, April 13, 1948, Papers of the NAACP, Part 26: Selected Branch Files, 1940 - 1955, Series A: The South, Reel 11, Group II, Box C-66, Frame 0586, Louisville, Kentucky, 1945-1949, Black Studies Research Sources.
} 
college chapter hosted youth aged 16-25. The presence of a separate NAACP college chapter in Louisville was not new; a short-lived chapter, housed at LMC, existed in the city from October 1937 until February 1938. Nor was the youth arm's work with the UL unfamiliar; during the early 1940s, the WEYC sponsored two interracial symposiums with guests representing the University.

Yet what made the 1948 resurgence of the college chapter unique was its interracial makeup. The president, Mr. Gaines Wilson, was an "energetic student" from the University of Louisville (UL); Miss Harriet Smith, a student at Louisville Municipal College, served as vice president; Miss Kathryn Jenkins, an employee of Southern Bell Telephone Company served as secretary; and Mr. Milton, a graduate of Central High, served as treasurer. ${ }^{112}$ Why, then, did the adult branch elect to have a college chapter led by both black and white students? It is most likely the adult chapter had its fight to desegregate Kentucky's graduate and professional schools in mind.

For the NAACP who believed "that change must come first to the border states before the Deep South could be breached," Border States served as tactical ground for laying the groundwork for the 1954 victory in Brown v. Board of Education. ${ }^{113}$ When Donald Murray, an African American, applied to law school at the University of Maryland, officials denied his admission. Due to the Separate-But-Equal doctrine, Maryland would have to construct a separate law school for African Americans, or integrate the University of Maryland's law school. Murray's case resulted in the integration of the law school in 1935. A nearly identical case occurred in Missouri in

\footnotetext{
112 Secretary's (Gladys C. Calhoun) Report, Date Unknown, Papers of the NAACP, Part 26: Selected Branch Files, 1940-1955, Series A: The South, Reel 11, Group II, Box C-67, Frame 0841, Louisville, Kentucky, 1950-1955, Black Studies Research Sources. It is unclear whether Kathryn Jenkins attended LMC or UL.

${ }^{113}$ Dittmer, Local People, 29.
} 
1938. When Lloyd Gaines, an African American, applied to law school at the University of Missouri, he was denied admission, and could not apply to a black law school in Missouri because one did not exist. The University of Missouri attempted to pay for Gaines to attend a law school outside of Missouri, but Gaines refused. Taking up Gaines' cause, the NAACP took the case to the Supreme Court. In Missouri ex. Rel Gaines v. Canada (1938), the Supreme Court ruled that unless a separate institution exists for African Americans, professional schools must integrate. ${ }^{114}$

With victories in Missouri and Maryland, Kentucky became the third border state to end Jim Crow schooling, an effort launched during the 1940s. The adult branch of the Louisville NAACP had been working to desegregate Kentucky's flagship university, the University of Kentucky (UK) since the early 1940s. Initially unsuccessful in its efforts, 1948 marked a renewed attempt to desegregate the university. On March 5, 1948, acclaimed educator and civil rights activist Lyman Johnson, who also served on the local branch's executive committee, applied for admission to the University of Kentucky's graduate school during the summer session. Eleven days later, he received notification that his application had been rejected. On June 19, Johnson traveled to Lexington in an attempt to register for classes. The Dean of Admissions/Registrar, stopped Johnson, citing Kentucky's Day Law, which legalized “separate-but-equal” education at all levels. ${ }^{115}$

Two days later, Johnson filed suit in federal district court to attempt to gain admittance into UK. Similar to Missouri officials' response to Gaines, the UK Board of

\footnotetext{
${ }^{114}$ Bynum, NAACP Youth, 12-13.

${ }^{115}$ McElhone, Civil Rights Activities, 100-105.
} 
Trustees sought to make Kentucky State College (KSC), one of Kentucky's colleges for African Americans, "equal." Attempting to avoid integration, the Board of Trustees promised to KSC students undergraduate work equal to that of UK, allowed students to take courses at UK not offered at KSC, and promised establishment of a graduate school. The trustees' concessions operated only under a façade of equality since segregation still existed and KSC resources and funding paled in comparison to that of UK. In March 1949, after a series of legal battles, a judge ruled that UK must integrate. That summer, Johnson and 29 other students became the first African Americans to attend UK. ${ }^{116}$ With this victory in hand, the Louisville NAACP turned to integrating the University of Louisville (UL), a struggle that began in September of 1949.

In September, Richard L. Dawson applied to the University of Louisville's School of Medicine, but officials rejected his application. Two months later on November 8, 1949, seven other African Americans applied to various graduate and professional schools at UL and were also rejected. That same month, the NAACP executive board filed a test case against UL. Initially working through the existing political structure, members of the executive committee met with the Board of Trustees on several occasions to "see what means can be worked out for a friendly adjustment to the situation." They were unsuccessful in their efforts. ${ }^{117}$

In March 1950, the NAACP gave UL five weeks to desegregate or the Association would file a lawsuit against the University. Hoping to avoid a prolonged legal battle, on April 19, 1950, the Board of Trustees agreed to admit African Americans

\footnotetext{
${ }^{116}$ Ibid.

${ }^{117}$ Ibid, 106-108.
} 
into graduate and professional schools in September 1950, and agreed to desegregate the undergraduate division in 1951, thus stimulating the closing of LMC. ${ }^{118}$

This context is vital to understanding the formation of the Louisville NAACP's interracial college chapter that received its official charter from the national office on July 15,1949 . Having desegregated the state's flagship university and having secured the guarantee of desegregating the city's leading university, 1949 proved a victorious year for the Louisville NAACP nationally, regionally, and locally. Because the interracial college chapter formed within the same timeframe that Johnson and the NAACP initiated its efforts to desegregate UK, and received its charter short of the months that the Board of Trustees agreed to desegregate UL, it is highly likely the adult branch established an interracial youth council, whose president was a student from UL, as a strategic act to encourage desegregation of Jim Crow schools locally and statewide.

NAACP college chapters were prevalent at white colleges and universities found in the North and Midwest during the 1940s. ${ }^{119}$ But Louisville was the (border) South, and as evidenced by the UL — LMC relationship, white colleges did not serve African Americans; thus LMC housed the college chapter. NAACP college chapters had to obtain consent from the national board of directors and college administrators to implement programming. From whom, then, did the college chapter obtain consent—administrators from the University of Louisville, from Louisville Municipal College, or administrators from each school?

It appears that the college chapter may have avoided these issues, as they participated in more social events - those that did not require official permission — than

\footnotetext{
${ }^{118}$ Ibid.

${ }^{119}$ Bynum, NAACP Youth, 166.
} 
choosing to enact a political agenda, which would have required consent. During the summer of 1949, members of the college chapter picnicked at Dr. Sweeney's farm. Sweeney, an African American dentist and member of the NAACP's executive committee, figured prominently in the Association's ongoing legal battle to desegregate Louisville's municipal parks. To grow their bond, the group also traveled to Clifty Falls, a state park located in Indiana, during the summer months. In October, the council raffled a barrel of groceries, totaling $\$ 66.00$. Proceeds from the raffle financed delegates' expenses to the National Youth Conference held in Dayton, Ohio. ${ }^{120}$

Just one day after seven African Americans applied unsuccessfully to UL, President Wilson and Vice President Smith, alongside another member, Mr. Lynes, were members of the three party delegation which traveled to "Gem City" for the conference. Alyce K. Holden, representing the adult branch, joined the delegates. Wilson had quite the impact upon the conference. Delegates elected Wilson the Assistant Secretary of the National Planning and Advisory Committee. Instituted in 1944, the Committee aided the national youth director in preparing and administering youth programs. ${ }^{121}$ Wilson also "figure[d] in a case arising from an effort to receive service in a Dayton Restaurant. The Youth Councils throughout the country [helped] to finance the expenses of the defendants in the case."122 The delegates' trip to the National Youth Conference, as far as the historical account suggests, marked the end of the college chapter's work. Though evidence is inconclusive, it appears that a youth arm in Louisville ceased to function from

\footnotetext{
${ }^{120}$ Secretary's (Gladys C. Calhoun) Report.

${ }^{121}$ Bynum, NAACP Youth, 67.

${ }^{122}$ Secretary's (Gladys C. Calhoun) Report.
} 
1950 until Muriel Gregg, elected in 1954 as the NAACP's national youth field secretary, reorganized the local youth council in $1955 .{ }^{123}$

The virtual disappearance of the Louisville NAACP youth from 1950 until 1955 came as a result of the Cold War between the United States and the Soviet Union during the late 1940s and early 1950s. The Cold War produced the Red Scare, a period during which the government sought to hunt down and expose any Americans whom they believed were members of the Communist Party or possessed ties to known Communists. Americans' fears were genuine, but that fear emanated out of the government's exploitation and propagandizing of the Red Scare than any genuine Communist threat that existed. Senator Joseph McCarthy and the Republican-led House Un-American Activities Committee (HUAC) led the effort to expunge "subversives," which included political liberals who worked in the US Department of State and Hollywood actors. ${ }^{124}$

The hypersensitive political climate led to a level of unprecedented political repression, which would eventually curtail efforts to gain civil rights for African Americans, especially in the South. As Jeff Woods writes in Black Struggle, Red Scare: Segregation and Anti-Communism in the South, 1948-1968, "The Southern Red Scare's core assumption [was] that racial reform was a plot hatched by foreign radicals." ${ }^{.125}$ As a consequence, southerners developed what historian John Dittmer calls a "siege mentality," censoring and repressing any entity that merely hinted at equality between the

\footnotetext{
${ }^{123}$ For more on Gregg's revamping of the national youth and college division, see Bynum, NAACP Youth, 68-69.

${ }^{124}$ For more information on HUAC, see "House Un-American Activities Committee" in The Encyclopedia of Civil Liberties in America, ed. David Schultz and John R. Vile (New York: M.E. Sharpe, 2005), 471-474.

${ }^{125}$ Jeff Woods, Black Struggle, Red Scare: Segregation and Anti-Communism in the South, 1948-1968 (Baton Rouge: Louisiana State University Press, 2004), 1.
} 
races. ${ }^{126}$ One such entity was the NAACP. As an organization whose founding and mission centered on securing equality for African Americans, the Association found itself the target of repression.

Though southerners exploited the Red Scare and succeeded in eradicating many NAACP branches throughout the South, the branches, by feeding into the political frenzy, played as significant of a role in their own repression as did white supremacists who sought to annihilate them. As Catherine Fosl writes in Subversive Southerner: Anne Braden and the Struggle for Racial Justice in the Cold War South, "In light of the Chinese Revolution, the Soviets' achievement of atomic capability, the Korean War, and the spy trials at home, the ethos of anticommunism had become so powerful by 1950 that some liberal groups [including the NAACP] began instituting their own internal noncommunist oaths, in effect conducting purges of their memberships. ${ }^{127}$ NAACP youth groups were not spared the scrutiny. Adult branches accused its youth councils and college chapters of having Communists fill its ranks. ${ }^{128}$

In Louisville, the NAACP was not spared the repression that inflicted branches across the South. The archival record does not contain any evidence that would substantiate that the adult branch or its youth arm were active between 1950 and 1953. Because the NAACP records allowed the government to identify "subversives," the adult branch may have made a deliberate choice to exclude documentation of their activities. The adult branch did include, however, newspaper clippings from 1954, a watershed year in Louisville's civil rights struggle.

\footnotetext{
${ }^{126}$ Dittmer, Local People, 58

${ }^{127}$ Catherine Fosl, Subversive Southerner: Anne Braden and the Struggle for Racial Justice in the Cold War South (Lexington: The University Press of Kentucky, 2002), 144.

${ }^{128}$ Bynum, NAACP Youth, 65-67.
} 
When Anne and Carl Braden, a white couple, purchased a home in Shively, an all-white suburb of Louisville for Charlotte and Andrew Wade, an African American couple, white supremacists dynamited the home. While the true perpetrators were never caught, the Bradens, as white allies in the struggle for racial justice, were charged with sedition. The local branch, given its ties to the Bradens, included a newspaper clipping documenting the Braden case in its archival record. ${ }^{129}$ Historian Luther Adams writes that the Association offered support to the Wade family, but broke ties with the Bradens, especially Anne, who took part in a NAACP membership campaign at the time she and Carl purchased the home for the Wades. James Crumlin, who had served as president of the local branch a few years earlier, asked Anne to withdraw her membership from the NAACP. ${ }^{130}$

The local branch, as did other branches, also began requiring its members to take oaths declaring their loyalty to the Association and the guarantee that they were not Communists, as evidenced by another newspaper clipping included in the archival record, "Local NAACP Sees Red; Asks for Loyalty Oath." ${ }^{131}$ Loyalty oaths apparently were not enough to convince the branch that subversives were not inundating its ranks. Given its ties to the Bradens and the sedition trial, in October 1954, George T. Corderay, then president of the adult branch, issued a letter of resignation, charging that "This branch has failed to protect the integrity of the NAACP.... One of the members of this branch's

\footnotetext{
${ }^{129}$ Newspaper photo, "Raiders Seize Literature At Home Of Bradens," Date unknown, Papers of the NAACP, Part 26: Selected Branch Files, 1940_1955, Series A: The South, Reel 11, Group II, Box C-66, Frame 0586, Louisville, Kentucky, 1945-1949, Black Studies Research Sources.

${ }^{130}$ Adams, Way Up North in Louisville, 2002, 218.

${ }^{131}$ Newspaper photo, October 14, 1954, Papers of the NAACP, Part 26: Selected Branch Files, 1940-1955, Series A: The South, Reel 11, Group II, Box C-66, Frame 0586, Louisville, Kentucky, 1945-1949, Black Studies Research Sources.
} 
executive committee, which is the heart and policy-making part of our organization, has been indicted by the Grand Jury for sedition. And, in addition, the other five indicted for the same charge, are also members of this organization..."132

The Braden Case, which swept the nation, was most illustrative of the way in which Southerners propagandized the pursuit of racial equality as a Communist front, ${ }^{133}$ and the ways in which the NAACP, including the Louisville chapter, had been almost "red scared out of existence" as a consequence of the political turmoil. ${ }^{134}$ Because of the upheaval, the adult branch likely had little time to devote to sponsoring a youth division, a fact substantiated by the lack of information in the archival record from $1950-1955$, which makes it impossible to conclude whether or not a youth arm remained in existence. Because the archival record suggests the youth arm was inactive, they were spared accusations by the adult branch of Communist ties, unlike a number of other youth councils. Thus the virtual disappearance of the Louisville NAACP youth from 1950 to 1955 is likely on trend with the rise of the Red Scare decline of the NAACP and its youth groups across the nation during the time, and not symptomatic of any issue specific to conflict between the adult branch and youth group(s) in Louisville.

\footnotetext{
${ }^{132}$ Letter from George C. Cordery to the Executive Board, October 5, 1954, Papers of the NAACP, Part 26: Selected Branch Files, 1940_-1955, Series A: The South, Reel 11, Group II, Box C-66, Frame 0586, Louisville, Kentucky, 1945-1949, Black Studies Research Sources.

${ }^{133}$ See Fosl, Subversive Southerner.

${ }^{134}$ Kendi, The Black Campus Movement, 51.
} 


\section{CHAPTER V}

CONCLUSION

"Each generation must out of relative obscurity discover its mission, fulfill it, or betray it. " ${ }^{135}$ Frantz Fanon, The Wretched of the Earth

\section{DISCUSSION}

$21^{\text {st }}$ century lynchings proliferate; African Americans' right to access public spaces is contested, enfranchisement is at stake, and the school-to-prison pipeline leaves black youth with a dismal prospect for the future. "The past refuses to lie down quietly." 136 The social, economic, and political forces that gave birth to the unrest in Baltimore and Ferguson are vestiges of the black freedom struggle's unfinished work. Though a spirit of nihilism permeates through these border cities, which are but microcosms of urban areas throughout the country, black youth, led primarily by young African American women, stand at the vanguard of social change, putting their lives on the line to remedy the contemporary manifestations of past racial ills. They do not stand alone in their fight; they stand on the shoulders of those ancestors, who in their youth, fought against racism and racial inequality.

As evidenced by the work of the youth arm of the Louisville NAACP, black

\footnotetext{
${ }^{135}$ Frantz Fanon, The Wretched of the Earth (New York: Grove Press, 1963), 206.

${ }^{136}$ South African Archbishop Desmond Tutu. As quoted in Hershini Bhana Young, Haunting Capital: Memory, Text and the Black Diasporic Body (Lebanon: Dartmouth College Press, 2006), 17.
} 
youth activists during the early period of the Civil Rights Movement also worked alongside adults, characteristic of youth-led social movements. ${ }^{137}$ Because of the organizational structure of the NAACP's national youth and college division, the youth arm followed the agenda of the national office, and when local youth councils and college chapters implemented programs, they had to obtain consent from adults of the NAACP. On its face, NAACP youth groups appear as puppets to the national office and local adult branches, but the youth and adults worked collaboratively, reinforcing and strengthening the work of the NAACP, nationally, regionally, and locally.

Many of the programs implemented by the Louisville NAACP youth groups were cooperative endeavors with the local adult branch. For example, in their first major campaign, the 1939 anti-lynching program, the youth council and college chapter 'secured the cooperation' of the adult branch in managing the logistics of the event. Similarly, in organizing the three-day youth conference during the interwar years, the East End Youth Council and West End Youth Council had then local NAACP President Lyman Johnson serve as a speaker, and capitalized on the networks of the adult branch by securing visitors from the University of Louisville.

Neither of these events would have been as successful had it not been for the shared work between the youth arm and adult branch. The effects of racism, classism, and sexism cannot be mitigated without collaborative efforts. As Sekou Franklin writes in After the Rebellion: Black Youth, Social Movement Activism, and the Post-Civil Rights Generation, "Because racial and class inequities are exacerbated by policies that cannot

${ }^{137}$ As Sekou Franklin writes in After the Rebellion: Black Youth, Social Movement Activism, and the PostCivil Rights Generation, "Youth or student-led movement organizations...interact with and are influenced by non youth groups and routinely rely on adult allies to assist with resource support, fund-raising, and capacity-building activities" (30). 
be resolved solely by young people themselves, student and youth activists must interact, form coalitions, and organize with veteran activists who make up complex movement infrastructures." 138

Though working alongside adults, the Louisville NAACP youth groups operated with much autonomy in the implementation of their political agenda. In some cases, they addressed issues that the adult branch did not. For example, the youth launched a letterwriting campaign protesting the anti-poll tax bill, and also wrote 'Letters to Hollywood' protesting stereotypical depictions of African Americans in television and film. In exercising their independence, the NAACP youth brought militancy and radicalism to the Movement. Franklin adds that in youth led social movements, "[Y]outh-led groups help to shape the political orientations of adult allies and often push more established leaders and groups to adjust their policy objectives." "139

For example, in Louisville, while the adult branch worked through the courts to open public accommodations, the youth took to the streets and launched a picket outside the Chestnut Street Health Center to articulate their discontent at closed accommodations. A prime example of dissident citizenship in action, the Louisville youth council utilized 'alternative public space' as a means to seek redress for its political grievance, rather than working through 'institutionalized democratic channels' as did the adults. ${ }^{140}$

By confronting issues that the adult branch did not, and by making use of noninstitutionalized means for social change, it is evident that the youth arm radicalized the NAACP's struggle to free Black Louisvillians from racism and racial inequality, a battle

\footnotetext{
${ }^{138}$ Franklin, After the Rebellion, 21.

${ }^{139}$ Ibid, 30.

${ }^{140}$ Sparks, "Dissident Citizenship,” 75.
} 
shaped by Louisville's place in the border region. Northern and southern "social forces that otherwise do not meet" ${ }^{\prime 141}$ converged to produce a form of white supremacy that gave birth to and shaped the Louisville youth's fight for equality.

The youth of the Louisville NAACP battled the same visible forms of white supremacy that their counterparts farther South confronted, such as closed accommodations, and most notably, a segregated and unequal educational system. Unlike the rest of the South, however, Louisvillians had access to the ballot, allowing activists to capitalize on their enfranchisement as leverage. Though most were not of voting age, the Louisville NAACP youth were still cognizant of the power of the ballot in the fight for freedom. For example, even though African Americans were not systematically disenfranchised in Louisville, working to eradicate the poll tax and ensuring black soldiers had the right to vote constituted a major part of the youth's political agenda.

The work and successes of the Louisville youth also highlights the important role of the presence and visibility of white allies in the black freedom struggle. The youth utilized racial diversity in both a practical and strategic manner at every critical juncture of their existence. First marked by the presence of Kellogg and Dunbar at the antilynching demonstration in 1938, during the 1940s, the youth capitalized on cross-racial alliances in their fight for educational equality. Most notably, the formation of the college chapter in 1948, headed by a white student, was a strategic act in the Louisville NAACP's campaign to desegregate higher education.

The struggle for equal education served as the definitive work of the Louisville NAACP youth arm. If the story of the Louisville NAACP youth from 1937 to 1955 is to serve as an example, then unequal education was the primary political grievance for black

\footnotetext{
${ }^{141}$ Lang, "Locating the Civil Rights Movement," 389.
} 
youth activists during the Civil Rights Movement's early period. In augmenting the work of the adult branch, which utilized its place in the border to facilitate the defeat of legalized racism, the Louisville NAACP Youth helped to facilitate passage of Brown v. Board of Education in 1954. When that historical moment came, it opened up a new era of organizing against segregation for the Louisville NAACP youth arm.

During the early winter and spring of 1961, Louisville's Youth Council launched an assault against Jim Crow, known as the "Nothing New for Easter" demonstrations, in the city's downtown business district. Engaging in sustained boycotts against cafeterias, theatres, and other accommodations that served the public helped to desegregate downtown Louisville, prompting the city, in 1963, to become the first city in the South to pass an ordinance banning discrimination in public accommodations. Passage of the ordinance was one of the outcomes of a series of events that began in 1955, when the Youth Council launched sit-ins at segregated drugstores in 1956 and two years later, when the mayor of Kingston, Jamaica was refused service at Walgreens, members of the Youth Council launched a sit-in in response.

\section{FUTURE RESEARCH}

The archival Papers of the NAACP, The Louisville Leader, and The Crisis were utilized to construct the narrative of the Louisville NAACP Youth from 1937 until 1955. Part of the difficulty in constructing the story lay in the fact that there were gaps in its timeframe. For example, these sources did not include information on the activities of the youth groups between 1946 and 1947. Future studies could utilize more mainstream sources such as the Louisville Courier Journal, to determine if 'white' newspapers 
covered any of the events of the Louisville NAACP youth arm. A more mainstream source could also provide additional historical context to aid in further analyzing the work of the Louisville NAACP youth. Furthermore, due to the time period under study, oral histories were not utilized. Oral histories, could, however, be conducted of any living descendants of the individuals who were members of the Louisville NAACP youth council(s) and college chapter(s).

One main contention in this thesis was that Louisville's place in the border region shaped and influenced its activism. But because of its focus on Louisville, the results are not generalizable. Future researchers could conduct a case study of NAACP youth councils and college chapters in the Border States to determine if the political agenda of other border councils and college chapters mirrored that of Louisville.

One unexpected finding in this narrative was the role of women in the Louisville NAACP youth's struggle for freedom. Young black women not only composed a larger membership, but also served as elected officers in the youth groups and were therefore responsible for erecting the political agenda. Young women such as Lavinia Sedwick and Minnie Harrison, who penned letters to congressmen protesting the anti-poll tax bill and petitioning for passage of the Soldier Vote Bill, are the progenitors of women such as Alicia Garza, Patrisse Cullors, and Opal Tometi, founders of the contemporary Black Lives Matter Movement.

Engendering Civil Rights Movement history has expanded conceptions of black women's leadership in the black freedom struggle, but has primarily focused on the role of adult women. What makes the young women of the Louisville NAACP particularly remarkable is that they were organizing for equality during a time in which gender norms 
placed women in the shadows of men. The young women who led the Louisville NAACP youth arm from 1937 until 1955 demonstrate that it is the obligation of scholars to now give young black women their place in the vast annals of history. 


\section{REFERENCES}

\section{Primary Sources}

\section{Archival Sources (Papers of the NAACP-microfilm)}

Papers of the NAACP, Part 12: Selected Branch Files, 1913-1939, Series A: The South,

Reel 12, Group I, Box G-77, Frame 1054, October-December 1937, Black

Studies Research Sources.

Papers of the NAACP, Part 19: Youth File, Series A: 1919-1939, Reel 4, Group I, Box E-

3, Frame 0027, Youth Council—Kentucky, 1937-1939, Black Studies Research

Sources.

Papers of the NAACP, Part 26: Selected Branch Files, 1940-1955, Series A: The South, Reel 11, Group II, Box C-66, Frame 0399, Louisville, Kentucky, 1940-1944, Black Studies Research Sources.

Papers of the NAACP, Part 26: Selected Branch Files, 1940-1955, Series A: The South, Reel 11, Group II, Box C-66, Frame 0586, Louisville, Kentucky, 1945-1949, Black Studies Research Sources.

\section{Newspapers/Periodicals}

The Louisville Leader

“2 KY. Senators Vote Yes But Cloture Motion Is Defeated: Both Parties Charged With Betraying Anti-Lynching Bill.” The Louisville Leader (Louisville, KY), Feb. 5, 1938.

“Mass Meeting.” The Louisville Leader (Louisville, KY), Feb. 5, 1938. 
"National Youth Anti-War Groups Meet in Columbus." The Louisville Leader

(Louisville, KY), January 14, 1939.

"New York Senator, Anti-Lynch Leader, Keynoter: Delegates from 27 States At Annual

Meet in Columbus.” The Louisville Leader (Louisville, KY), July 2, 1938.

“Women's Committee For Local Association Branch Organized." The Louisville Leader

(Louisville, KY), Dec. 17, 1938.

The Crisis

“A Fine Conference Held in Columbus.” The Crisis, August 1938.

"Branches and Youth Councils and their Christmas Seal Chairman.” The Crisis, April 1940.

"Christmas Seals." The Crisis, February 1940.

Current, Gloster B. “Detroit’s Multiple Youth Councils.” The Crisis, May 1939.

"Filibuster Continues on Anti-Lynch Bill.” The Crisis, February 1938.

"New Youth Leaders." The Crisis, July 1939.

Rosenberg, Samuel A. "Negro-Managed Cooperatives in Virginia." The Crisis, September 1940.

"Spring Campaigns.” The Crisis, April 1940.

“Spring Membership Campaign.” The Crisis, June 1939.

"To Push Registration and Aid Fight on Textbooks." The Crisis, August 1938.

“Women's Committee Formed for Louisville Branch.” The Crisis, January 1939.

"Youth Council Activities: Louisville, Ky. (East End)." The Crisis, October 1943.

"Youth Council Activities: Louisville, Ky. (West End)." The Crisis, October 1943.

"Youth Council News—Activities: Louisville, Ky." The Crisis, July 1941. 
"Youth Council News: Willkie Building Fund.” The Crisis, April 1945.

\section{Secondary Sources}

\section{Books}

Adams, Luther. Way Up North in Louisville: African American Migration in the Urban

South, 1930-1970. Chapel Hill: The University of North Carolina Press, 2010.

Arnesen, Eric, ed. “Don’t Buy Where You Can't Work' Campaigns.” In Encyclopedia of

U.S. Labor and Working-Class History, Volume I, 380-382. New York:

Routledge, 2007.

Bates, Beth Tompkins. Pullman Porters and the Rise of Protest Politics in Black

America, 1925-1945. Chapel Hill: The University of North Carolina Press, 2001.

Berg, Manfred. “The Ticket to Freedom”: The NAACP and the Struggle for Black

Political Integration. Gainesville: University Press of Florida, 2005.

Biondi, Martha. To Stand and Fight: The Struggle for Civil Rights in Postwar New York

City. Cambridge: Harvard University Press, 2003.

Brown, Nikki L.M. and Barry M. Stentiford, eds. "Double V Campaign.” In Jim Crow: A Historical Encyclopedia of the American Mosaic, 139-142. Santa Barbara: ABCCLIO, Inc., 2014.

Bynum, Thomas L. NAACP Youth and the Fight for Black Freedom, 1936-1965.

Knoxville: The University of Tennessee Press, 2013.

Cohen, Robert. When the Old Left Was Young: Student Radicals and America's First Mass Student Movement, 1929-1941. New York: Oxford University Press, 1993.

Committee On Un-American Activities. Nominating Petitions for 1940 Elections Under the Title and Designation of Communist Party, various States: Official Report 
Prepared by and for the Confidential Use of the Special Committee on UnAmerican Activities (1936).

Countryman, Matthew J. Up South: Civil Rights and Black Power in Philadelphia. Philadelphia: University of Pennsylvania Press, 2007.

Denning, Michael. The Cultural Front: The Laboring of American Culture in the Twentieth Century. New York: Verso, 1997.

Dittmer, John. Local People: The Struggle for Civil Rights in Mississippi. Champaign: University of Illinois Press, 1994.

Eick, Gretchen Cassel. Dissent in Wichita: The Civil Rights Movement in the Midwest, 1954-72. Champaign: University of Illinois Press, 2007.

Fanon, Frantz. The Wretched of the Earth. New York: Grove Press, 1963.

Finch, Minnie. The NAACP: Its Fight for Justice. New Jersey: The Scarecrow Press, Inc., 1981.

Fosl, Catherine and Tracey E. K'Meyer. Freedom on the Border: An Oral History of the Civil Rights Movement in Kentucky. Lexington: The University Press of Kentucky, 2009.

Fosl, Catherine. Subversive Southerner: Anne Braden and the Struggle for Racial Justice in the Cold War South. Lexington: The University Press of Kentucky, 2002.

Franklin, Sekou M. After the Rebellion: Black Youth, Social Movement Activism, and the Post-Civil Rights Generation. New York: New York University Press, 2014.

Garland, Sarah. Divided We Fail: The Story of an African American Community That Ended the Era of School Desegregation. Boston: Beacon Press, 2013. 
Gellman, Erik S. Death Blow to Jim Crow: The National Negro Congress and the Rise of Militant Civil Rights. Chapel Hill: The University of North Carolina Press, 2003.

Gilmore, Glenda. Defying Dixie: The Radical Roots of Civil Rights, 1919-1950. New York: W.W. Norton \& Company, 2008.

Johnson, Kimberley. Reforming Jim Crow: Southern Politics and State in the Age Before Brown. New York: Oxford University Press, 2010.

Jonas, Gilbert. Freedom's Sword: The NAACP and the Struggle Against Racism in America, 1909-1969. New York: Routledge, 2005.

Jones, Patrick D. The Selma of the North: Civil Rights Insurgency in Milwaukee. Cambridge: Harvard University Press, 2009.

Kellogg, Charles Flint. NAACP: A History of the National Association for the Advancement of Colored People: Volume I. Baltimore: The John Hopkins Press, 1967.

Kelley, Robin D.G. Hammer and Hoe: Alabama Communists During the Great Depression. Chapel Hill: The University of North Carolina Press, 1990.

Kendi, Ibram. The Black Campus Movement: Black Students and the Racial Reconstitution of Higher Education, 1965-1972. New York: Palgrave Macmillan, 2012.

Kerr, Daniel R. Derelict Paradise: Homelessness and Urban Development in Cleveland, Ohio. Amherst: University of Massachusetts Press, 2011.

Kleber, John E. ed., “Civil Rights.” In The Encyclopedia of Louisville, 190-193. Lexington: The University Press of Kentucky, 2001. 
Kleber, John E. ed., "Day Law.” In The Kentucky Encyclopedia, 258-259. Lexington: The University Press of Kentucky, 1992.

Kleber, John E. ed., "Hotels and Motels." In The Encyclopedia of Louisville, 404-406. Lexington: The University Press of Kentucky, 2001.

Kleber, John E. ed., "Kentucky Negro Educational Association.” In The Kentucky Encyclopedia, 507. Lexington: The University Press of Kentucky, 1992. Kleber, John E. ed., "Louisville Leader." In The Encyclopedia of Louisville, 557. Lexington: The University Press of Kentucky, 2001.

Kleber, John E. "Louisville Municipal College." In The Encyclopedia of Louisville, 562. Lexington: The University Press of Kentucky, 2001.

K'Meyer, Tracy E. Civil Rights in the Gateway to the South: Louisville, Kentucky, 19451980. Lexington: The University Press of Kentucky, 2009.

Korstad, Robert. Civil Rights Unionism: Tobacco Workers and the Struggle for Democracy in the Mid-Twentieth Century. Chapel Hill: The University of North Carolina Press, 2003.

Levy, Peter B. Civil War on Race Street: The Civil Rights Movement in Cambridge, Maryland. Gainesville: University Press of Florida, 2003.

Lucander, David. Winning the War for Democracy: The March on Washington Movement, 1941 - 1946. Champaign: University of Illinois Press, 2014.

Mack, Dwayne A. Black Spokane: The Civil Rights Struggle in the Inland Northwest. Norman: University of Oklahoma Press, 2014.

Meier, August and Elliot Rudwick. Along the Color Line: Explorations in the Black Experience. Champaign: The University of Illinois Press, 1976. 
Miller, Karen R. Managing Inequality: Northern Racial Liberalism in Interwar Detroit. New York: New York University Press, 2015.

Mokyr, Joel ed. "New Deal." In The Oxford Encyclopedia of Economic History, Volume 1, 71-74. New York: Oxford, 2003.

Morris, Aldon. The Origins of the Civil Rights Movement: Black Communities Organizing for Change. New York: The Free Press, 1984.

Moye, J. Todd. "Focusing Our Eyes on the Prize: How Community Studies are Reframing and Rewriting the History of the Civil Rights Movement." In Civil Rights History from the Ground Up: Local Struggles, a National Movement, edited by Emilye Crosby, 147-171. Athens: University of Georgia Press, 2011.

Newman, Mark. The Civil Rights Movement. Westport: Praeger Publishers, 2004.

Proudfoot, Merill. Diary of a Sit-In. Chapel Hill: The University of North Carolina Press, 1962.

Rustin, Bayard. Down the Color Line: The Collected Writings of Bayard Rustin. Chicago: Quadrangle Books, 1971.

Sartain, Lee. Borders of Equality: The NAACP and the Civil Rights Struggle, 1914-1970. Jackson: University Press of Mississippi, 2013.

Sartain, Lee. Invisible Activists: Women of the Louisiana NAACP and the Struggle for Civil Rights, 1915-1945. Baton Rouge: Louisiana State University Press, 2007.

Schultz, David and John R. Vile, eds. "House Un-American Activities Committee.” In The Encyclopedia of Civil Liberties in America, 471-474. New York: M.E. Sharpe, 2005. 
Self, Robert O. "Negro Leadership and Negro Money”: African American Political Organizing in Oakland before the Panthers." In Freedom North: Black Freedom Struggles Outside the South, 1940-1980, edited by Jeanne F. Theoharis and Komozi Woodard, 93-124. New York: Palgrave Macmillan, 2003.

Smith, John Clay. Emancipation: The Making of the Black Lawyer, 1844-1944. Philadelphia: The University of Pennsylvania Press, 1993.

Sullivan, Patricia. Lift Every Voice: The NAACP and the Making of the Civil Rights Movement. New York: The New Press, 2009.

Sutherland, Jonathan, ed. "March on Washington (1941).” In African Americans at War: An Encyclopedia, Volume 1, 259-261. Santa Barbara: ABC-CLIO, Inc., 2004.

Theoharis, Jeanne and Komozi Woodard, eds. Freedom North: Black Freedom Struggles Outside the South, 1940-1980. New York: Palgrave Macmillan, 2003.

Theoharis, Jeanne and Komozi Woodard, eds. Groundwork: Local Black Freedom Movements in America. New York: NYU Press, 2005.

Thernstrom, Stephan and Abigail Thernstrom. America in Black And White: One Nation Indivisible. New York: Touchstone, 1997.

Turner, Joyce Moore and W. Burghardt Turner. Caribbean Crusaders and the Harlem Renaissance. Champaign: University of Illinois Press, 2005.

Tyler, Bruce Michael. African-American Life in Louisville. Charleston: Arcadia Publishing, 1998.

Tyler, Bruce Michael. Images of America: Louisville in World War II. Charleston, Arcadia Publishing, 2005. 
Whitaker, Matthew C. Race Work: The Rise of Civil Rights in the Urban West. Lincoln: University of Nebraska Press, 2007.

Wilkerson, Isabel. The Warmth of Other Suns: The Epic Story of America's Great Migration. New York: Vintage Books, 2010.

Wolcott, Victoria W. Race, Riots, and Roller Coasters: The Struggle Over Segregated Recreation in America. Philadelphia: The University of Pennsylvania Press, 2012. Woodley, Jenny. Art for Equality: The NAACP's Cultural Campaign for Civil Rights. Lexington: The University Press of Kentucky, 2014.

Woods, Jeff. Black Struggle, Red Scare: Segregation and Anti-Communism in the South, 1948-1968. Baton Rouge: Louisiana State University Press, 2004.

Wright, George C. Racial Violence in Kentucky, 1865-1940: Lynchings, Mob Rule, and 'Legal Lynchings.' Baton Rouge: Louisiana State University Press, 1990.

Young, Hershini Bhana. Haunting Capital: Memory, Text and the Black Diasporic Body. Lebanon: Dartmouth College Press, 2006.

\section{Online Resources}

“Charles Ewbank Tucker.” Accessed May 7, 2015.

http://nkaa.uky.edu/record.php?note_id=32.

“History.” United Service Organizations. Accessed April 22, 2015. http://www.uso.org/history.aspx.

“Jennie B. Liggin.” Accessed May 7, 2015. http://nkaa.uky.edu/record.php?note_id=2480.

“Kentucky Negro Educational Association.” Accessed April 22, 2015. http://nkaa.uky.edu/record.php?note_id=410. 
"YWCA (Louisville, KY).” Accessed May 17, 2015.

http://nkaa.uky.edu/record.php?note_id=1696

\section{Scholarly Articles}

Farrington, Joshua D. "Even I Voted Republican”: African American Voters and Public Accommodations in Louisville, Kentucky, 1960-1961." Register of the Kentucky Historical Society 109, 3 \& 4 (2011).

Hall, Jacquelyn Dowd. "The Long Civil Rights Movement and the Political Uses of the Past." The Journal of American History 91, no. 4 (2005): 1233-1263.

Lang, Clarence. "Locating the Civil Rights Movement: An Essay on the Deep South, the Midwest, and Border South in Black Freedom Studies." Journal of Social History 47, no. 2 (2013): 371-400.

Meier, August. "Negro Protest Movements and Organizations." The Journal of Negro Education 32, no. 4 (1963): 437-450.

Morris, Aldon. "Black Southern Sit-In Movement: An Analysis of Internal Organization." American Sociological Review 46, no. 6 (1981): 744-767.

Smith, Gerald L. "Direct Action Protests in the Upper South: Kentucky Chapters of the Congress of Racial Equality in Register of the Kentucky Historical Society." Register of the Kentucky Historical Society 109, 3 \& 4 (2011): 351-393.

Sparks, Holloway. "Dissident Citizenship: Democratic Theory, Political Courage, and Activist Women." Citizenship in Feminism: Identity, Action, and Locale 12, no 4 (1997): 74-110. 


\section{Unpublished Works}

Adams, Luther. "Way Up North in Louisville: African-American Migration in Louisville, Kentucky, 1930-1970.” PhD diss., University of Pennsylvania, 2002.

McElhone, Patrick S. "The Civil Rights Activities of the Louisville Branch of the National Association for the Advancement of Colored People: 1914-1960.” Thesis, University of Louisville, 1976. 


\section{CURRICULUM VITAE}

Alexis Monique Johnson

308 Airport Lane

Apt. 15

Cheraw, SC 29520

(843) 910-0828

alexisjohnson1128@yahoo.com

\section{EDUCATION}

Master of Arts in Pan-African Studies, University of Louisville, Louisville, KY, Aug. 2015

Concentration: African American Studies

Thesis: "What Role We, As Negro Youth of America, Could Play": A New History of the Louisville NAACP Youth, 1937-1955

Bachelor of Arts in English-Liberal Arts (Summa Cum Laude), Francis Marion University, Florence, SC, May 2013

\section{ACADEMIC HONORS AND ACTIVITIES}

Graduate Dean's Citation (M.A.)

President's List, Dean's List

Model United Nations, delegate

English Award

McCrimmon Award for Excellence in Undergraduate Writing

Gender Studies Competition, $2^{\text {nd }}$ Place

Student Marshal

Honor Student Association, Member

PROFESSIONAL SOCIETIES

Phi Kappa Phi

Sigma Tau Delta

Omicron Delta Kappa

\section{GRADUATE ASSISTANTSHIP}

Anne Braden Institute for Social Justice Research, University of Louisville, Aug. 2013May 2015 


\section{CONFERENCE PRESENTATIONS}

Muhammad Ali Institute for Peace and Justice Student Conference, Louisville, Kentucky, Mar. 2015. "Repression Breeds Resistance: The Birth of the Kentucky Alliance Against Racist and Political Repression."

A.C.E.S. KY: Black and Latino Student Symposium, Louisville, Kentucky, Feb. 2015. "Digital Desegregation." (Panel with Angelica Bullock and Joshua Schuschke) Individual Presentation: " $20^{\text {th }}$ Century Struggles for Educational Equality and Inclusion: Black High School Students Fight Back.”

National Council for Black Studies $38^{\text {th }}$ Annual Conference, Miami Florida, Mar. 2014. Black Political and Intellectual Leadership in the $20^{\text {th }}$ Century I. (Panel with Schetauna Powell and Megan Pavageau). Individual Presentation: "Warring Ideals in Four Dark Bodies: Ghana, Pan-Africanism and Black Political Leadership."

International Writing Center Association Conference, Ft. Lauderdale, Florida, Feb. 2013. "Venturing into the Realm of Journalism: Tutoring Your Student Newspaper Staff." (Presentation with Justin McGee)

International Writing Center Association Conference, San Diego, California, Oct. 2012. "Effective Strategies for Synchronous Online Tutorials." (Poster Presentation with Dr. Jennifer Kunka, Anthony Gregg, and Justin McGee)

Without Sanctuary: Lynching and the American South, Charlotte, North Carolina, Oct. 2012. "Black Christ: An American Apocalyptic Theme."

Coker Undergraduate Humanities Conference, Hartsville, South Carolina, Feb. 2012. "Black Christ: An American Apocalyptic Theme."

International Writing Center/National Association of Peer Tutors Conference, Baltimore, Maryland, Nov. 2011. "Strategies for Coping with Tutorials of Distress." (Panel with Dr. Jennifer Kunka, Josh Knight, Melody Pritchard, Jessica Upchurch)

Popular Culture Association of the South Regional Conference, Savannah, Georgia, Oct. 2010. "Examining our Roots: African American Women and Hair."

\section{TUTORING EXPERIENCE}

Writing Center Consultant, Francis Marion University, Jan. 2010-May 2013

Peer Advisor, Francis Marion University Office of Career Development, Sept. 2011-May 2013

English 111 Lab Tutor, Francis Marion University English 111 Lab, Aug. 2011-Dec. 2011

\section{EDITORIAL EXPERIENCE}

Managing Editor: The Patriot, Francis Marion University, May 2012-May 2013

Staff Writer: The Patriot, Francis Marion University, Aug. 2010-May 2011

Peer Reviewer: Writing Lab Newsletter, Feb 2011-May 2011

\section{ACTIVITIES}

Pan-African Graduate Student Association, Member (Sept. 2013-May 2015), Treasurer (Aug. 2014-May 2015)

Catholic Campus Ministries, Member and Public Relations Officer (Aug. 2011-May 2013) 
University Programming Board, Member (Aug. 2011-May 2012). 